
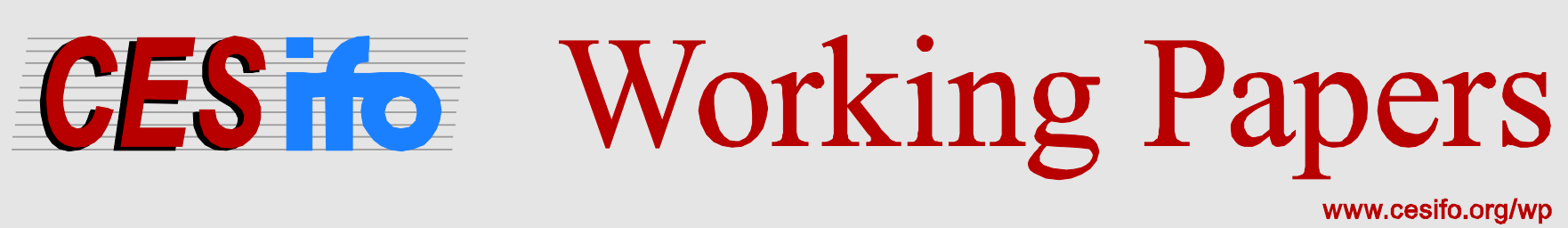

\title{
The Consumption Effects of the 2007-2008 Financial Crisis: Evidence from Houshold-level Data
}

\author{
Thais Lærkholm Jensen \\ Niels Johannesen
}

CESIFO WORKING PAPER NO. 5600

CATEGORY 1: PUBLIC FINANCE

NOVEMBER 2015
An electronic version of the paper may be downloaded
- from the SSRN website:
- from the RePEc website:
- from the CESifo website:
wWw.SSRN.com
www.RePEc.org
www.CESifo-group.org/wp




\title{
The Consumption Effects of the 2007-2008 Financial Crisis: Evidence from Houshold-level Data
}

\begin{abstract}
Did the financial crisis spread from distressed banks to households through a contraction of the credit supply? We study this question with a dataset that contains observations on all accounts in Danish banks as well as comprehensive information about individual account holders and banks. We show that banks exposed to the financial crisis reduced their credit supply significantly and that their customers reduced both borrowing and consumption relative to customers in nonexposed banks. The credit supply channel can explain roughly one third of the decrease in aggregate private consumption observed in Denmark between 2007 and 2009.
\end{abstract}

JEL-Codes: D120.

Keywords: relationship banking, financial crisis, household consumption, household credit.

Thais Lerkholm Jensen Department of Economics University of Copenhagen

Øster Farimagsgade 5 Denmark - 1353 Copenhagen K tlj@econ.ku.dk
Niels Johannesen Department of Economics University of Copenhagen Øster Farimagsgade 5 Denmark-1353 Copenhagen K niels.johannesen@econ.ku.dk

October 2015

We thank John Campbell, Samuel Hanson, Rajkamal Iyer, Jonathan Parker, Atif Mian, Søren Leth-Petersen, Ramana Nanda, Victoria Ivashini, José-Luis Peydro, Martin Simmler and Adi Sundaram along with seminar participants at Harvard Business School, MIT Sloan School of Management, Norwegian Business School, Pompeu Fabra University and the University of Copenhagen for helpful comments and suggestions. We acknowledge generous financial support from the Economic Policy Research Network. Part of the research was carried out while Thais Lærkholm Jensen and Niels Johannesen were visiting researchers at Harvard Business School and the University of Michigan respectively and the hospitality of these institutions is gratefully acknowledged. The viewpoints expressed in this paper do not necessarily reflect those of the Danish Central Bank. All errors are our own. 


\section{Introduction}

The global banking crisis in 2007-2008 was followed by the Great Recession where corporate investment, employment and household consumption fell sharply in virtually all developed countries. This pattern of a financial bust followed by a severe contraction of the real economy has played out numerous times over the last centuries (Reinhart \& Rogoff, 2009).

A central question faced by economists trying to grasp the dynamics of the Great Recession is whether the crisis in the banking sector was transmitted to the real economy through a reduction in credit supply. The tightening of credit by banks in financial distress is one among several possible explanations why firms stopped investing and households reduced consumption in the aftermath of the financial crisis. Understanding the strength of this transmission mechanism is important for guiding policy responses to future crises. To the extent that tightened credit is responsible for the transmission to the real economy, it may be possible to contain a financial crisis by securing credit to the firms and households served by banks in distress.

This paper explores how the financial crisis in 2007-2008 affected the borrowing and consumption of households through the credit supply channel. Our laboratory is Denmark where households, like in the U.S. and many other advanced economies, are highly levered and thus depend strongly on credit to sustain consumption.

We exploit a unique dataset from the Danish tax authorities, which contains information about the balance of all loan accounts in Danish financial institutions for the period 2003-2011, and add comprehensive information about account holders from administrative records as well as balance sheet information about banks. We can thus track the borrowing of households in each bank and assess the extent to which they reduced total borrowing or compensated with borrowing from other banks when their existing bank tightened credit. We can also estimate the effects on real estate and automobile choices as well as total spending imputed from income and wealth information (Browning \& Leth-Petersen, 2003).

Our empirical strategy exploits that the financial crisis in 2007-2008 affected Danish banks differentially depending on the structure of their balance sheet. While the origin of the crisis was losses on US mortgage-backed securities, it spread within the banking sector through the markets for short-term funding (Brunnermeier, 2009; Shin, 2009; Gorton \& Metrick, 2012). Danish banks generally had limited direct exposure to US mortgage-backed securities (Rangvid, 2013), however, those that relied heavily on wholesale funding experienced a severe liquidity shock when funding markets 
froze in 2008. Hence, the financial crisis plausibly induced a differential credit supply shock to Danish households because banks with a stable funding base and relatively liquid assets were able to continue lending as before, whereas banks with an unstable funding base and relatively illiquid assets were forced to reduce their lending.

Based on these considerations, we measure a bank's exposure to the financial crisis and thus the severity of the credit supply shock suffered by its customers with the ratio of loans to deposits in 2007 where the denominator reflects relatively illiquid assets and the denominator reflects relatively stable funding. We document that banks with a higher ratio of loans to deposits in 2007 reduced lending significantly over the period 2008-2011 relative to other banks, which is consistent with existing studies of lending dynamics during the financial crisis (Ivashina \& Scharfstein, 2010; Cornett et al., 2011) and arguably driven by a tightening of the credit supply.

In the main analysis, we match each individual with their primary bank in 2007 and follow their credit and consumption outcomes over time. We then ask whether individuals who in 2007 were customers in banks that were exposed to the imminent financial crisis fared worse in subsequent years than others. More precisely, we identify how the financial crisis affected households through the credit supply channel by comparing customers in banks with an above-median ratio of loans to deposits ("exposed banks") to customers in banks with a below-median ratio of loans to deposits ("non-exposed banks"). ${ }^{1}$

The key challenge for identification is that banks' exposure to the financial crisis may conceivably correlate with the credit demand of their customers. Such a correlation could arise if exposed banks were also characterized by other imprudent business practices such as low credit standards and lax monitoring of borrowers. This could cause selection into exposed banks by inherently impatient individuals who borrowed beyond their means before the crisis and thus demanded less credit after the crisis. In this example, simply comparing the credit outcomes of customers in exposed and nonexposed banks would conflate demand and supply factors and therefore not correctly identify the credit supply channel.

We address this identification issue in various ways. First, we show that the observable characteristics of customers in exposed and non-exposed banks were virtually identical. Seemingly, the two types of banks served the same household segments at the eve of the crisis suggesting that they were exposed to the same demand shocks. Second, our model eliminates several confounding factors by including individual fixed

\footnotetext{
${ }^{1}$ We show in the Appendix that our results also hold in specifications that use the ratio of loans to deposits as a continuous measure of exposure to the crisis.
} 
effects as well as a comprehensive set of pre-crisis individual characteristics interacted with time dummies. For instance, non-parametric controls for the pre-crisis distribution of debt interacted with time dummies effectively control for differential credit demand shocks arising from differences in pre-crisis leverage (Dynan et al., 2012). In a similar way, we eliminate credit demand shocks arising from differences in municipality, industry, income, age, education and so on. Third, we show that pre-crisis trends in outcomes are parallel across individuals whose banks were exposed differently to the crisis. This strengthens the case that unobservable individual characteristics affecting credit demand are uncorrelated with bank exposure. Finally, we exploit that a non-trivial number of individuals have loans in two or more banks to estimate an account-level model where individual-time fixed effects fully absorb credit demand shocks. This model cleanly identifies the credit supply channel by comparing lending to the same individual by banks with different exposure to the financial crisis (Khwaja \& Mian, 2008).

The first set of results provides strong evidence that the financial crisis reduced household borrowing through the credit supply channel. The total debt of customers in exposed banks decreased by around DKK 14,200 (USD 2,000) relative to customers in non-exposed banks with most of the divergence occurring in 2008-2009 when the financial crisis was at its peak. The drop in total debt reflects a decrease in credit from the pre-crisis primary bank and an increase in credit from other banks, which implies that around half of the decrease in lending by exposed banks was neutralized by their customers borrowing more in other banks.

Supporting the notion that the relative decrease in borrowing by customers in exposed banks was involuntary and driven by tightened credit supply, we present evidence on borrowing constraints. Most individuals in Denmark have a tax favored pension savings account funded by mandatory employer contributions, however, a steep penalty for liquidation makes this an undesirable source of liquidity for individuals with access to credit. We show that such liquidations increased significantly for customers in exposed banks relative to customers in non-exposed banks. Although the average effect on liquidity was modest, around DKK 100 (USD 14) over the postcrisis period, the result is highly suggestive that customers in exposed banks were more likely to experience severe borrowing constraints.

To strengthen the case for a causal interpretation of these results, we show that unemployment and disposable income followed the same trends for customers in exposed and non-exposed banks throughout the sample period. This reassures us that the estimates are not confounded by unobserved customer-level shocks to creditwor- 
thiness or liquidity correlating with bank-level exposure to the financial crisis.

The second set of results shows that the decrease in borrowing was accompanied by a significant decrease in consumption. The annual spending of customers in exposed banks decreased by around DKK 4,200 (USD 600) relative to customers in nonexposed banks. Most of this effect is explained by a decrease in spending on real estate: customers in exposed banks bought smaller and less expensive houses relative to customers in non-exposed banks. But other consumption margins adjusted too: customers in exposed banks became less likely to own at least one car and less likely to own multiple cars relative to customers in non-exposed banks.

The spending estimates allow us to ask how much of the drop in aggregate private consumption observed in Denmark after the financial crisis can plausibly be explained by the credit supply channel. We find that the direct effect of tightened bank credit on non-real estate spending, a reasonable approximation to standard measures of consumption, can account for roughly one third of the $4 \%$ drop in private consumption in national accounts from the peak in 2007 to the trough in 2009.

The last set of results explores the role of bank switches in mitigating the adverse effects of credit supply shocks. While bank switches are generally endogenous to credit demand, we exploit that a number of distressed banks were resolved by the regulatory authorities during the financial crisis. Their assets and liabilities, including all customer accounts, were transferred to sound banks, thus creating bank switches that are plausibly uncorrelated with credit demand.

We find that customers in failed banks had significantly better credit outcomes than customers in banks that were exposed to the crisis but did not fail and, in fact, fared just as well as customers in non-exposed banks. This may seem at odds with our previous findings since failure, where a bank stops granting credit altogether, is in a sense the ultimate credit supply shock. However, in the present context where accounts in failed banks are mechanically transferred to sound banks, it is clearly consistent with a positive effect of credit supply on borrowing. From a policy perspective, the finding that bank switches can causally improve credit outcomes points to the removal of barriers to customer mobility as a measure that may alleviate the repercussions of banking crises in the real economy.

While our empirical results are generally difficult to reconcile with theoretical models of frictionless banking markets, they are consistent with different types of frictions: a cost of switching banks on the customer-side (Klemperer, 1987), which makes some individuals stay with their existing bank even when they could have obtained better credit outcomes in other banks, and imperfect information on the 
bank-side, which creates ex ante uncertainty about default probabilities (Sharpe, 1990) and deters banks from lending to new customers. Both frictions imply that some customers in exposed banks obtain less credit than they would have as customers in non-exposed banks; and that bank failures may improve credit outcomes by inducing a transfer of customer accounts and credit records to sound banks, which mitigates the adverse effects of switching costs and imperfect information respectively.

The main contribution of the paper is to enhance our understanding of the sharp decrease in household consumption that often follows a financial crisis. Existing studies emphasize the role of excessive leverage (Mian \& Sufi, 2010), falling house prices (Mian et al., 2013) and increased uncertainty (Alan et al., 2012) whereas our analysis points to a complementary channel through the contracted credit supply of distressed banks.

The existing literature linking financial crises to household outcomes through the credit supply channel is small and has produced mixed results. Two papers show that banks with high exposure to the 2007-2008 financial crisis reduced their lending to households in its aftermath (Ramcharan et al., 2015; Puri et al., 2011). While these findings suggest that the credit supply channel contributed to the drop in consumer demand for housing and automobiles after the financial crisis, the papers only consider bank-level outcomes and therefore cannot determine whether customers in exposed banks were able to compensate with borrowing from other sources and thus ultimately maintain their desired level of consumption. One paper addresses this issue by combining bank and household survey data from Canada and concludes that the financial crisis had no effect on household consumption through the credit supply channel (Damar et al., 2014). ${ }^{2}$

The paper proceeds in the following way. Section 2 provides background information on the financial crisis in Denmark. Section 3 describes the data sources and reports summary statistics. Section 4 discusses the empirical strategy. Sections 5 and 6 present the results concerning financial outcomes and consumption outcomes, respectively. Section 7 studies the role of bank switches in mitigating the adverse effects of credit supply shocks. Section 8 discusses the implications of the results for aggregate consumption. Section 9 concludes.

\footnotetext{
${ }^{2}$ The credit supply channel is more thoroughly documented in the context of firms. A number of papers demonstrate that firms' borrowing decreases when their bank relation is in distress (Khwaja \& Mian, 2008; Jiménez et al., 2014) and point to real effects in terms of reduced investment (Klein et al., 2002; Dwenger et al., 2015) and employment (Chodorow-Reich, 2014; Bentolila et al., 2015).
} 


\section{Background}

\subsection{The Danish financial sector}

The Danish financial sector counts more than 100 retail banks, however, the bank market is relatively concentrated: 5 systemically important banks account for the majority of all lending while the remaining banks are predominantly regional or local banks.

The most distinctive feature of the Danish financial sector is the important role played by specialized mortgage credit institutions. These institutions are much more regulated than retail banks. They are only allowed to lend with collateral in Danish real estate and the loan-asset ratio on their loans cannot exceed $80 \%$ at origination. Moreover, they must be fully funded with publicly traded bonds and are required to lend at the interest rate at which they borrow plus a fixed premium covering average credit risk.

While consumer and auto loans are typically granted by banks and never involve mortgage credit institutions, most real estate purchases are financed with credit from both sources: a senior loan from a mortgage credit institution up to the regulatory limit and a junior loan from a bank that finances the residual. This implies that banks are typically the marginal providers of mortgage credit to households and that the credit limit set by banks determines the total amount of mortgage credit available to their customers. We therefore focus on the role of banks' credit supply in shaping credit and consumption outcomes of households.

\subsection{The financial crisis 2007-2008 and its aftermath}

In the years before the global financial crisis in 2007-2008, the Danish economy was growing at a rapid pace, the real estate market was booming and banks expanded their lending substantially. Since lending grew much faster than deposits, some banks relied increasingly on international credit markets to finance their expansion, often through loans at short maturities IMF (2014).

While Danish banks generally had very limited exposure to the U.S. mortgagebacked securities that triggered the financial crisis, some banks reached dangerously low levels of liquidity when global markets for wholesale funding froze (Rangvid, 2013; Shin, 2009). Between May and September 2008, the central bank therefore intervened several times to provide liquidity to the banking system and in October 2008, shortly after the collapse of Lehmann Brothers, the government was compelled 
to extend a two-year unlimited guarantee to all bank liabilities. Despite the massive efforts to sustain the financial sector, many banks were in serious distress: 15 banks were closed by the regulatory authorities between 2008 and 2011 and many others accepted mergers to avoid failure reducing the total number of licensed banks from 147 in 2007 to 113 in 2011 (Rangvid, 2013).

A severe crisis in the real economy accompanied and aggravated the banking crisis. Between 2007 and 2009, real private consumption decreased by around 4\%, real GDP by around $5 \%$, real investment by around 18\%, real housing prices by around $20 \%$ and stock prices by more than $40 \%$.

Figure 1 tracks our two key outcomes over the boom and bust. ${ }^{3}$ It shows a rapid increase in households' bank credit and consumption until the peak of the financial crisis in 2008 when the expansion of credit suddenly came to a halt and consumption dropped sharply. The ultimate goal of the paper is to investigate how much of the decline in consumption can be explained with a decrease in banks' credit supply.

\section{[Figure 1 around here]}

\subsection{The differential credit supply shock}

The main premise of our analysis is that banks with fewer deposits on the liability side of their balance sheet and more loans on the asset side, tightened their credit supply more in response to the financial crisis.

Figure 2 provides evidence in support of this premise. While banks with a ratio of loans to deposits above and below the median (measured in 2007) exhibited very similar growth rates in lending during the period 2005-2007, there was a sharp divergence over the period 2008-2012: whereas banks with a low loan-deposit ratio continued to expand lending, banks with a high loan-deposit ratio reduced lending considerably in a sudden reversal of the trend in the previous years. Table 1 shows that the negative correlation between banks' pre-crisis loan-deposit ratio and subsequent growth in lending is statistically significant, regardless of whether the regressions are unweighted or weighted with bank size and whether the loan-deposit ratio is used as

\footnotetext{
${ }^{3}$ The analysis in this and the following subsection is conducted on the basis of the MFI Statistics published by the Danish Central Bank, which excludes the smallest banks. Hence, the number of banks in the analysis is smaller than the total number of licensed banks reported above.
} 
a continuous variable or transformed into a dummy variable indicating a loan-deposit ratio above the sample median. These results are in line with existing studies of bank lending during the financial crisis (Ivashina \& Scharfstein, 2010; Cornett et al., 2011).

\section{[Figure 2 around here]}

While the bank-level analysis is consistent with a differential credit supply shock that caused a decrease in the borrowing of customers in banks exposed to the crisis, it has at least two shortcomings. First, it is not clear whether customers in exposed banks were affected at all; based on the evidence presented above it cannot be excluded that the diverging lending outcomes of exposed and non-exposed banks were driven by customers switching from the former to the latter and thus neutralizing the effect of differential credit supply shocks. Second, we cannot be sure whether the bank-level lending patterns reflect differential supply or demand shocks; strictly speaking it could be customers' demand for credit that for one reason or the other correlated with banks' loan-deposit ratios rather than banks' own credit supply.

[Table 1 around here]

For these reasons, our main analysis studies outcomes at the individual level and at the even more granular account level. This allows us to study the full effect of credit supply shocks on bank customers while taking into account substitution toward other sources of credit and controlling for confounding changes in credit demand.

\section{Data}

\subsection{Variables, sources and sample}

The main data innovation of this paper is to establish a link between individuals and their bank relations from tax records. At the end of each year, financial institutions in Denmark report the balance of their customers' deposit and loan accounts to

\footnotetext{
${ }^{4}$ Figure A1 in the Appendix shows how the mean loan-deposit ratio evolves over the sample period for banks with a loan-deposit ratio above and below the median in 2007: the difference between the two means is roughly constant until 2008 with some convergence in the later years as banks with a high initial loan-deposit ratio reduces this ratio significantly.
} 
the tax authorities. The reports are compulsory and reliable since they are used for tax enforcement. We thus have a complete mapping of all loans and deposits with domestic financial institutions held by all individuals in Denmark. ${ }^{5}$

To the raw administrative records of the Danish tax authorities, we add comprehensive information about the individual account holders from a number of other administrative registers. This includes demographic information such as age, gender, education, home municipality and identity of children and parents; labor market information such as wage income, industry and unemployment spells; income and wealth information such as capital income, social transfers, value of stock portfolios and pension accounts; auto register information such as the weight and production year of each registered automobile; real estate register information such as the size and value of each registered property. We also add detailed balance sheet information about the reporting banks obtained from the Danish Central Bank.

In the resulting dataset, we thus observe the following information for all individuals resident in Denmark for the period 2003-2011: the balance of each of their loan and deposit accounts; balance sheet information about the bank in which the account is held; and comprehensive background information about individual account holders from government registers.

Before conducting the analysis, we restrict the sample in several ways. First, we remove self-employed individuals since it is generally not possible to separate borrowing for business and private purposes on the balance sheet of those operating a firm in their own name. Second, we restrict the sample to individuals who were between 20 and 50 years in 2007 so that retirement decisions do not confound our analysis. Third, we exclude individuals whose primary bank in 2007 failed during the period 2008-2011 because a bank failure may affect customers in a fundamentally different way than a tightening of credit standards. We analyze the credit outcomes of customers in failed banks separately in section 7 . Finally, we study a $25 \%$ random sample of the resulting population for computational tractability. This leaves us with a baseline sample of around 440,000 individuals, almost 3.5 million individual-years and more than 5.7 million individual-account-years.

\footnotetext{
${ }^{5}$ In practice, we obtain the link between individuals and banks in the following way. The first four digits of the bank account numbers that we observe in the tax records uniquely identify the branch of the bank where the accounts are held in a given year. We then hand-collect lists of branch idnumbers and the corresponding banks from publications by Nets, a payment solutions provider, for each of the years 2003-2011. This establishes the dynamic link between individual account numbers and bank identity.
} 


\subsection{Imputed spending}

One of our key outcome measures is spending, which we impute from income and wealth variables. The main idea is that spending in a given period, by definition, equals disposable income minus the increase in net wealth. Hence, to the extent that disposable income and wealth can be measured precisely, it is possible to infer the level of spending as:

$$
\text { spending }_{i t}=\text { disposable }_{\text {income }} i t-\left(\text { net wealt } h_{i t}-\text { net wealt } h_{i t-1}\right)
$$

Several papers show that while imputed measures of spending are noisy, they contain significant information about true spending, notably for individuals with simple balance sheets (Browning \& Leth-Petersen, 2003; Kreiner et al., 2014).

Since we do not observe the true market value of real estate but only the assessed value for tax purposes, we choose to exclude real estate from the wealth measure. This implies that our spending measure, contrary to standard measures of consumption, includes purchases of real estate. For individual-years where no purchase or sale of real estate takes place, our spending measure is conceptually similar to the consumption measure used in national accunts.

One of the components of net wealth is stock portfolios, which are measured at market value. Since our income measure does not include unrealized capital gains, increases in stock prices raise measured spending by increasing net wealth while leaving income unchanged. We address this error in two ways. First, our main regressions with spending exclude the roughly 20 percent of individuals who own stocks in a given year. Second, when our regressions include such individuals, we impute their unobserved capital gains by applying the price change of the market portfolio. With this procedure, stock price changes do not lead to a measurement error in imputed spending for individuals who hold the market portfolio, but will cause it to be overestimated (underestimated) for individuals whose stock portfolio underperforms (overperforms) relative to the market portfolio.

\subsection{Summary statistics}

Once the dataset is constructed, we define a unique primary bank for each individual in 2007 using the following procedure: ${ }^{6}$ For individuals who only had one bank relation in 2007, this is their primary bank. For individuals who had multiple bank relations in 2007, but only had a loan in one of those banks, this is their primary

\footnotetext{
${ }^{6}$ To be precise, the primary bank is always a bank and not a mortgage institution.
} 
bank. For individuals who had loans in multiple banks in 2007, the bank in which the loan balance was largest is their primary bank. For individuals who had no loans, but had deposits in multiple banks in 2007, the bank in which the deposit balance was largest is their primary bank. The procedure thus rests on the assumptions that loans provide a stronger bank relation than deposits and that bank relations are stronger the larger the account balance.

Next, we order individuals according to the loan-deposits ratio of their primary bank in 2007 and split the sample at the median individual so that the number of individuals with exposed and non-exposed banks is approximately the same. ${ }^{7}$

Table 2 reports pre-crisis summary statistics on the main variables used in the analysis for customers in banks with high and low ratios of loans to deposits separately. All variables measured in DKK are winsorized at the 1st and 99th percentiles to reduce the influence of extreme observations. The summary statistics provide a sense of the demographic characteristics and financial situation of the individuals in our sample. Individuals were roughly equally distributed across the four education categories, around two thirds had a cohabitating partner and more than half had children. The average total income was around DKK 250,000 (USD 35,000) and the average disposable income after taxes and interest payments around DKK 200,000. Since the average imputed spending was around DKK 220,000, we can infer that the average individual reduced net wealth by around DKK 20,000 in 2007. The average level of debt was around DKK 500,000 (USD 70,000) implying a ratio of debt to income around 2, which is very high by international standards and higher than in, for instance, the U.S.

\section{[Table 2 around here]}

The summary statistics also allow us to assess whether pre-crisis customers in banks with high and low loan-deposit ratios were different with respect to their observed characteristics and, hence, whether it is a priori likely that the divergence in lending by the two types of banks was driven by differential credit demand shocks. This does not seem to be the case. Table 2 shows that customers in banks with high and low loan-deposit ratios are strikingly similar. None of the differences between variable means in the two samples are close to statistical significance. Hence, there

\footnotetext{
${ }^{7}$ The small discrepancy is due to the fact that the individuals right below and right above the median who are customers in the same bank are assigned to the same group.
} 
are no signs of customer selection into exposed banks based on observable household characteristics.

Finally, the table illustrates the important role of specialized mortgage credit institutions: around one third of household loans in Denmark is from banks while the remaining two thirds is almost exclusively from mortgage credit institutions. Although our empirical strategy only exploits variation in the credit supply of banks, the significance of non-bank debt makes it imperative to study total debt as a separate outcome. Given the institutional framework explained in section 2.1, we expect loans from banks and mortgage credit institutions to be complements: since bank customers typically cannot increase the share of financing from mortgage credit institutions in response to a tightening of bank credit, they are likely to purchase less real estate, which reduces borrowing from both banks and mortgage credit institutions in absolute terms.

\section{Empirical strategy}

The aim of the empirical analysis is to estimate the effect of banks' credit supply on the credit and consumption outcomes of households. Our main empirical strategy is to compare individuals, whose primary bank was exposed to the global liquidity shock associated with the financial crisis and therefore reduced its credit supply, to individuals whose primary bank was less exposed to the financial crisis. We implement this comparison with the following baseline model:

$$
\text { outcome }_{i t}=\alpha_{i}+\gamma \Omega_{t}+\beta \Omega_{t} \times \text { exposed }_{i}+\delta \Omega_{t} \times X_{i}+\epsilon_{i t}
$$

where outcome $i t$ is a financial or consumption outcome of individual $i$ at time $t$;

$\alpha_{i}$ represents individual fixed effects; $\Omega_{t}$ is a vector of time dummies (2007 is the

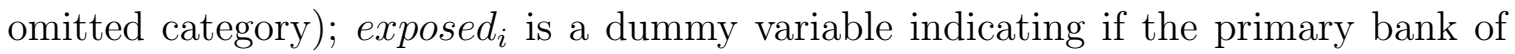
individual $i$ in 2007 had a loan-deposit ratio above the population median; and $X_{i}$ is a vector of characteristics of individual $i$ in 2007 .

The estimated vector $\beta$ contains the main coefficients of interest. For each year it measures the average change in the outcome variable relative to 2007 for individuals who were customers in exposed banks in 2007 over and above the average change over the same period for individuals who were customers in non-exposed banks. The baseline model thus yields difference-in-difference estimates of how the financial crisis 
affected households through the credit supply channel for each of the years 2008-2011.

The key methodological challenge is that credit demand shocks could correlate with credit supply shocks, which would invalidate inference based on a simple comparison of customers in exposed and non-exposed banks. For instance, it may be that customers in exposed banks incidentally had educational backgrounds, lived in geographical regions or worked in industries that made them more affected by the crisis through other channels. Alternatively, they may have had different unobserved characteristics, such as risk attitudes or time preferences, which made them behave differently during the crisis. In either case, the credit demand shocks of individuals may have varied systematically with the exposure of their bank. We address this identification issue in various ways.

First, the difference-in-difference estimates are computed conditional on a comprehensive set of controls. For each control variable, we include the value in 2007 as well as its interactions with year dummies. With this procedure we effectively identify the effect from a comparison of individuals with the same observed characteristics in 2007, of which some were customers in exposed banks and others were customers in non-exposed banks. To the extent that credit demand evolved similarly for customers in exposed and non-exposed banks with the same observed characteristics, the baseline model therefore correctly identifies the credit supply channel.

The baseline model includes variables that capture the following characteristics: gender (dummy for being a woman), age (dummies for each 1-year age group), education (dummies for short, medium and long education with no education as the omitted category), home ownership (dummy for owning real estate), children (dummy for having children), civil status (dummy for cohabitation with partner), student (dummy for being a student), unemployment (dummy for unemployment spells during 20062007), bank debt (dummies for the deciles of the bank debt distribution in 2007), income (dummies for the deciles of the income distribution in 2007), income growth (dummies for the deciles of the distribution of income changes over the period 20032007), home municipality (dummy for each of 98 Danish municipalities), and industry (dummy for each of 9 occupation sectors).

Second, $\beta$ allows us to assess directly whether customers in exposed and nonexposed banks followed similar trajectories in terms of borrowing and consumption over the period 2003-2007 conditional on observed characteristics. If trends in outcomes are parallel during a period where there was presumably no major differential shocks to credit supply, it is suggestive that the unobserved characteristics shaping credit demand are roughly balanced across customers in the two types of banks. 
Finally, we estimate the following account-level model that absorbs all variation in credit demand with individual-year fixed effects:

$$
\text { outcome }_{i b t}=\theta_{i t}+\phi \Omega_{t} \times \text { exposed }_{b}+\mu_{i b t}
$$

where outcome $e_{i b t}$ is the outcome of individual $i$ in bank $b$ at time $t ; \theta_{i t}$ represents individual-time fixed effects; and exposed ${ }_{b}$ is a dummy variable indicating if bank $b$ had a loan-deposit ratio above the median in 2007. The model includes no covariates since individual characteristics as well as their interactions with year dummies are absorbed by the individual-time fixed effects.

In the account-level model, $\phi$ measures the change in borrowing by a given individual in exposed banks over and above the change in borrowing by the same individual in non-exposed banks. Given that the individual-year fixed effects capture the credit demand of each individual at each point in time, any differential changes in borrowing across different banks can be attributed to differential changes in the credit supply. This is essentially the within-estimator proposed by Khwaja \& Mian (2008).

It should be noted that $\phi$ is not identified when there is only one observation per individual-year. The model can therefore only be applied to credit outcomes and $\phi$ is here identified exclusively by individuals with loan accounts in more than one bank. While such individuals do not constitute a random subset of the total population and the results from this model do therefore not necessarily generalize to the full sample, the account-level model nevertheless remains a useful framework for testing the power of the credit-supply channel in a setting where potentially confounding credit demand factors are effectively eliminated.

Another potential identification problem derives from the fact that even banks with a low loan-deposit ratio may have been affected by the financial crisis and may consequently have tightened their credit supply, although presumably to a lesser extent than banks with a high loan-deposit ratio. To quantify the credit supply effect of the financial crisis, we effectively use customers in banks with low loandeposit ratios as a counterfactual for customers in banks with high loan-deposit ratios, which is only accurate to the extent that the credit supply in the former banks was completely unaffected by the financial crisis. In a sense, our estimates therefore provide a lower bound on the true effect of the financial crisis through the credit supply channel.

While the baseline specifications uses a dichotomous measure of bank exposure to the financial crisis, our results are very similar when we replace exposed with the loan-deposit ratio and thus use the variation in exposure within the groups of exposed 
and non-exposed banks. These main results with this specification are reported in Table A2 in the Appendix.

Finally, we note that all point estimates are reported with standard errors clustered at the level of the primary bank in 2007. This conservative clustering strategy widens the standard errors considerably given that the baseline sample includes close to 3.5 million observations at the individual-year level, but only 128 banks.

\section{Results: Financial outcomes}

We first use the baseline model with individual fixed effects and a full set of controls to study individuals' total debt. This outcome comprises bank debt as well as debt in specialized mortgage institutions. Figure 3 plots the estimated coefficients on the interaction terms between the year dummies and the dummy variable indicating that the individual's primary bank in 2007 was exposed to the financial crisis (i.e. the elements in the vector $\beta$ ). The precise point estimates and standard errors are available in Table A1 in the Appendix.

\section{[Figure 3 around here]}

For 2004-2006, the point estimates are almost precisely zero suggesting that the average total debt of customers in exposed and non-exposed banks grew at almost exactly the same speed before the financial crisis. For 2008-2011, the point estimates are below zero suggesting that the total debt of customers in exposed banks decreased relative to the total debt of customers in non-exposed banks after the financial crisis. The point estimates are highly statistically significant. Since our observations are endof-year, the gradually decreasing point estimates of around $-4,000$ for 2008, $-12,000$ for 2009 and $-15,000$ for 2010 imply that most of the divergence between customers in the two types of banks occurred in the course of 2009.

Next, we conduct the same exercise using bank debt as the outcome variable. Figure 4 shows a similar pattern as the previous figure. The relatively small point estimates for 2004-2006 suggest that customers in exposed and non-exposed banks followed very similar trajectories until 2007 whereas the negative and gradually decreasing point estimates for 2008-2011 suggest that customers in exposed banks experienced falling bank debt relative to customers in non-exposed banks from 2008. In absolute terms, the estimated effects are somewhat smaller for bank debt than for total debt with point estimates hovering around -7,000 in 2009-2011. This confirms our 
expectation that loans from banks and mortgage institutes are complements so that a reduction in bank debt induced by tightened bank credit spills over on non-bank debt.

\section{[Figure 4 around here]}

While Figures 3 and 4 showed the results from the full baseline model, we now estimate a more compact version of the baseline model where outcomes are averaged over the periods 2005-2007 ("pre-crisis") and 2009-2011 ("post-crisis"). Since we collapse the time dimension of the dataset to two periods, the vector of time dummies is replaced with a simple post-crisis dummy. The compact model is useful because it sums up the bank supply channel in a single coefficient, the interaction term between exposed and post, which enhances comparability between different specifications.

Equipped with this model, we study how the large set of controls shapes our results by moving sequentially from a specification with no controls, which is essentially a raw comparison of average levels, to the full specification will all controls. Column (1) in Table 3 implies that the average total debt was DKK 7,611 higher for customers in exposed banks than for customers in non-exposed banks in the pre-crisis years whereas it was DKK 8,698 lower in the post-crisis years, a relative decrease of DKK 16,309. To this most parsimonious specification, Column (2) adds covariates, municipality dummies and industry dummies, all interacted with year dummies. While the pre-crisis level difference in total debt between customers in exposed and non-exposed banks almost vanishes and the R-squared increases considerably, the key estimate, the decrease in total debt of customers in exposed banks relative to customers in non-exposed banks, is barely affected. Hence, observed characteristics are successful at explaining level-differences in total debt, but are almost orthogonal to the growth-differences between customers in the exposed and non-exposed banks. Column (3) finally adds individual fixed effects, which also leaves the key estimate virtually unchanged.

\section{[Table 3 around here]}

We then present similar results for various bank debt outcomes. As shown in Columns (4)-(6), customers in exposed banks decreased their total bank debt by 
around DKK 7,000 relative to customers in non-exposed banks. This reflects a decrease in debt in the bank that served as primary bank in 2007 of around DKK 14,000, as shown in Columns (7)-(9), and an increase in debt in other banks of around DKK 7,000, as shown in Columns (10)-(12). These results are informative about the extent to which households mitigated bank-level credit supply shocks by switching banks. Specifically, they suggest that customers in banks exposed to the financial crisis neutralized roughly half of the effect of tightened credit in their primary bank by obtaining credit in other banks.

To address the concern that the baseline model does not account for differential changes in credit demand driven by differences in unobserved characteristics, we now turn to the account-level model described in the previous section. It should be noted that loan balances are considerably more difficult to model at the account-level than at the individual-level. For instance, when an existing loan is refinanced in a new bank, we observe a large increase in the account-level balance in the new bank and a corresponding decrease in the account-level balance in the old bank whereas the individual-level balance is unchanged. This variability in account-level balances tends to increase standard errors considerably. Our preferred outcome variable is therefore a dummy variable indicating a positive change in the balance of a pre-existing loan account. The transformation of the dependent variable to a dummy variable eliminates the problem of highly volatile account-level loan balances.

Figure 5 illustrates the results by plotting the estimated coefficients on the interaction terms between the year dummies and the dummy variable indicating that the bank was exposed to the financial crisis (i.e. the elements in the vector $\phi$ ). The full regression output is available in Table A1 in the Appendix.

\section{[Figure 5 around here]}

The coefficients are very close to zero for the years 2004-2006, hence there was no change in the likelihood of increasing the loan balance in exposed banks relative to the likelihood of increasing the loan balance in non-exposed banks for individuals who held loan accounts in both types of banks during the pre-crisis period. For 2009 , the coefficient is significantly negative and the point estimate suggests that individuals with multiple accounts were $15 \%$ less likely to increase the loan balance in exposed banks than in non-exposed banks compared to the pre-crisis period. For 2010 and 2011, the point estimates are also negative, but not statistically significant. 
The finding that most of the decrease in borrowing in exposed banks occurred in the course of 2009 is consistent with the results from the baseline model.

Since the individual-year fixed effects in the account-level model effectively absorb the credit demand of each individual at each point in time, it is difficult to explain these results in other ways than that exposed banks tightened their credit supply relative to non-exposed banks after the financial crisis. This further strengthens the credibility that the results from the baseline model are driven by differential credit supply shocks rather than credit demand shocks.

Having established that the differential credit supply shock induced by the financial crisis affected credit outcomes in the household sector, we now study whether there was an effect on financial assets. It is conceivable that individuals whose access to credit was constrained responded by running down financial assets and this mechanism may prevent a decrease in credit from causing a decrease in consumption (Damar et al., 2014). Table 4 reports the results. As shown in Columns (1)-(2), customers in exposed banks reduced the value of their bank deposits and stock portfolios slightly relative to customers in non-exposed banks. However, the combined decrease in liquid assets of DKK 1,111 is modest relative to the corresponding decrease in debt of DKK 14,230 (from Table 3, Column 3) and not statistically significant.

\section{[Table 4 around here]}

The finding that exposed banks reduced their credit supply and that their customers were unable to compensate fully with credit from other sources suggest that customers in exposed banks were more likely to become borrowing constrained after the crisis. We study this proposition using liquidations of tax favored pension savings accounts as an indicator of borrowing constraints. While such accounts are funded by mandatory employer contributions and thus available to most individuals in Denmark, a $60 \%$ penalty applying to liquidations before pension age makes it a very costly source of liquidity, which we should expect individuals to use only when alternative sources of liquidity are exhausted. This claim is substantiated in Figure 6 , which displays a strong correlation between the ratio of liquid assets to disposable income and withdrawals from tax favored pension savings accounts: almost $6 \%$ of individuals with low liquid assets made withdrawals in 2009 compared to only $3 \%$ of individuals with high liquid assets.

We estimate the baseline model with withdrawals from tax favored pension savings 
accounts as dependent variable and find that customers in exposed banks increased the withdrawals significantly relative to customers in non-exposed banks, as shown in Column (3) of Table 4. While the average annual liquidity effect of DKK 36 (i.e. DKK 108 over the period 2009-2011) is modest, the finding is suggestive that the weakening of banks after the financial crisis imposed relatively severe borrowing constraints on some households. ${ }^{8}$

\section{[Figure 6 around here]}

Finally, we consider two non-financial outcomes, disposable income and unemployment, which may influence banks' effective credit supply to households and could therefore possibly confound our results. If customers in exposed banks suffered decreases in their income and increases in their unemployment risk relative to customers in non-exposed banks with the same observed characteristics, the implied deterioration in creditworthiness could potentially explain why the former obtained less credit than the latter. As shown in Column (4) of Table 4, we find a small differential decrease in disposable income of around DKK 350 for customers in exposed banks. The effect is far from statistical significance and relatively precisely estimated: the lower confidence bound on the relative decrease in income is around DKK 1,700, which is much smaller than the relative decrease in credit of around DKK 14,200. Moreover, as illustrated in Figure 7, there is no clear trend over the sample period that could explain the differential decrease in credit for customers in exposed banks. ${ }^{9}$ Finally, as shown in Column (5) of Table 4, we find a small and statistically insignificant differential decrease in unemployment for customers in exposed banks. If anything, this would tend to increase their creditworthiness and therefore cannot explain the observed differential decrease in borrowing.

\section{[Figure 7 around here]}

\footnotetext{
${ }^{8} \mathrm{We}$ find the same pattern when we use a binary indicator of withdrawals.

${ }^{9}$ We have also estimated the baseline model for credit outcomes while adding contemporaneous disposable income to the set of explanatory variables and this has virtually no impact on the results (not reported).
} 


\section{Results: Consumption outcomes}

We start the analysis of consumption outcomes by estimating the baseline model with individual fixed effects and a full set of controls using imputed spending as the dependent variable. The sample conservatively excludes individuals who own stocks since capital gains accruing differentially to customers in exposed and non-exposed banks could potentially confound our results.

As shown in Figure 8, the estimated coefficients on the key interactions between exposed and year dummies are small for the years 2004-2006 suggesting that spending by customers in exposed and non-exposed banks evolved similarly before the financial crisis. In 2008-2009, however, there was a significant differential decrease in spending by customers in exposed banks. Specifically, from 2007 to 2008, their spending fell by around DKK 4,500 relative to customers in non-exposed banks, and from 2008 to 2009 by an additional DKK 4,500. Over the next years, the spending of customers in exposed banks slowly caught up with the spending of customers in non-exposed banks.

[Figure 8 around here]

It is important to note that since spending is a flow variable, it is natural that the differential decrease suffered by customers in exposed banks after the financial crisis was temporary. In other words, a temporary drop in current spending and a subsequent catch-up imply a permanent effect on cumulative spending, which is consistent with the permanent effect on total debt reported in the previous section. In terms of timing, the results for spending and debt also tell a coherent story: the relative drop in current spending between 2007 and 2009 coincided with the large relative drop in the debt level and the catching up from 2010 occurred when the debt level stabilized.

Next, we estimate the compact version of the full baseline model for a number of consumption-related outcome variables and report the results in Table 5. Column (1) shows that the differential decrease in spending over the period 2009-2011 was DKK 3,811 in the baseline sample without stock-owners and highly statistically significant. Column (2) shows that this effect increases slightly when stock-owners are included in the sample.

[Table 5 around here] 
In the following columns, we study automobile consumption. Column (3) shows that the number of cars owned by customers in exposed banks dropped by 0.00276 relative to customers in non-exposed banks. This suggests that 1 out of roughly 350 customers in exposed banks owned 1 car less than they would have owned, had they been customers in non-exposed banks. Column (4) shows that the relative drop in car ownership mostly concerns multiple car ownership. The propensity to own two cars or more dropped by 0.00153 suggesting that 1 out of roughly 650 customers in exposed banks owned at most one car whereby they would have owned at least two cars, had they been customers in non-exposed banks. Column (5) shows a relative decrease in the average weight of cars owned by customers in exposed banks of around 2.7 kilo or roughly $0.2 \%$ given the sample average of around 1,400 kilo. Since car weight has been shown to be a reasonable proxy for car value (Munk-Nielsen, 2015), the small and statistically insignificant point estimate suggests that customers in exposed banks did not adjust car consumption on the intensive margin. These results point to a relatively modest effect of the financial crisis on automobile consumption through the credit supply channel. To illustrate, assuming realistically that a car in Denmark is worth on average DKK 100,000, the point estimate of 0.00276 suggests that the extensive margin of auto ownership can account for around DKK 276 of the relative decrease in spending suffered by customers in exposed banks.

Turning to housing outcomes, Column (6) shows that the average public property valuation of homes owned by customers in exposed banks decreased by DKK 10,240 relative to customers in non-exposed banks. This suggests that individuals with a demand for better housing were more likely to remain in their existing home or acquire a less expensive home than desired if they were customers in exposed banks.

Zooming in on the latter channel, we proceed to estimate models where the sample is restricted to individual-years where a real estate purchase takes place. In this modified version of the baseline model, we effectively compare a different set of individuals in each year: customers in exposed banks who bought real estate during the relevant year and customers in non-exposed banks who bought real estate during the same year. Compared to the full baseline model, we drop individual fixed effects to avoid restricting the identifying variation to the limited number of individuals who buy several homes during the sample period, but retain all other controls.

Column (7) shows that the increase in the public property valuation triggered by a real estate transaction fell by DKK 34,644 for customers in exposed banks relative to customers in non-exposed banks. Similarly, as shown in Column (8), there was a differential decrease in the average new debt of DKK 27,038 and, as shown in Column 
(9), a differential decrease in the gain in home size of 0.489 square meters for customers in exposed banks purchasing real estate. These results are strongly suggestive of customers in exposed banks were induced to buy smaller and less valuable homes when their banks tightened credit in response to the financial crisis.

\section{Results: The role of bank switches}

This section highlights how bank switches mitigate the transmission of a bank crisis to the real economy. As a first motivating exercise, we estimate the credit supply effect separately for the roughly one third of the sample who switched banks during the post-crisis period and the roughly two thirds of the sample who did not. Table 6 reports the results. Column (1) shows that, in the sample of switchers, credit outcomes are virtually identical across individuals coming from exposed and nonexposed banks whereas Column (2) shows that, in the sample of non-switchers, the borrowing of customers in exposed banks dropped by around DKK 21,600 relative to customers in non-exposed banks. These findings imply that the mean decrease in borrowing of around DKK 14,200 identified in the baseline model is entirely driven by non-switchers, however, the interpretation is complicated by the endogenous nature of bank switches. Notably, the incentive to leave a bank with a low credit supply is arguably strongest for customers who demand but are not granted new credit, hence switchers are likely to have a larger average credit demand than non-switchers. ${ }^{10}$

[Table 6 around here]

To overcome the endogeneity problem, we exploit that a number of distressed banks were resolved by the regulatory authorities during the financial crisis and their assets and liabilities assumed by sound banks. For the customers whose accounts were transferred to the acquiring bank in the process of the resolution, this arguably represents an exogenous change in their bank relation. We thus augment the baseline sample with customers in failed banks and estimate a version of the regression model that includes a separate trend for these individuals. As shown in Column (3), customers in failed banks fared much better in terms of credit outcomes than customers in exposed, but surviving banks and, strikingly, just as well as as customers in non-

\footnotetext{
${ }^{10}$ This is corraborated in the data where the average bank switch is accompanied by a significant increase in borrowing.
} 
exposed banks. The result is suggestive that moving to a bank with less exposure has a causal effect on credit.

The finding is puzzling if one emphasizes that bank failure is the ultimate credit supply shock where lending stops entirely. From this perspective, we should expect customers in failed banks to have worse credit outcomes than any other group. It can be rationalized, however, by emphasizing the role of failures in facilitating bank switching. If the banking market is characterized by frictions that preclude customers in banks with a low credit supply from switching to banks with a high credit supply, then the failure of the former banks and mechanical transfer of their customers to the latter banks should be expected to improve credit outcomes.

\section{Discussion: The macro-implications}

This section uses our micro-based estimates to discuss how much of the drop in aggregate private consumption illustrated in Figure 1 that can plausibly be explained by a tightening of bank credit.

As shown in Figure 7, the differential decrease in spending by customers in exposed banks between 2007 and 2009 was around DKK 8,500. This number includes spending on real estate, which is not consumption in the sense used by national accounting where purchases of real estate are treated as investment. To obtain comparable estimates net of real estate spending, we repeat the estimation while excluding individual-years where a real estate transaction takes place. The point estimates imply a differential decrease in the non-real estate spending of customers in exposed banks of around DKK 6,200 between 2007 and 2009, which corresponds to $2.8 \%$ of their total spending in 2007 (reported in Table A1 in the Appendix).

By comparison, aggregate private consumption dropped by around $4 \%$ in real terms between 2007 and 2009. Since our estimate of $2.8 \%$ only applies to half of the population, those who were customers in exposed banks, our results suggest that the credit supply channel can explain a decrease in aggregate consumption of 1,4\% or roughly one third of the total drop in aggregate private consumption from the pre-crisis peak in 2007 to the post-crisis trough in 2009.

There are several reasons to believe, however, that this simple computation underestimates the full impact of the credit supply channel. First, our identification rests on a comparison between customers in exposed and non-exposed banks and therefore effectively assumes that non-exposed banks did not change their credit supply after the financial crisis. If non-exposed banks did in fact tighten credit, albeit 
less than exposed banks, this would tend to bias our estimates toward zero. Second, the direct effect of credit supply on consumption plausibly created multiplier effects. Since these indirect effects are likely to be similar for customers in exposed and non-exposed banks, they are not captured by our estimates. Third, the decrease in real estate spending does not in itself reflect a decrease in consumption, but may have affected consumption indirectly through its effect on house prices. The estimated decrease in real estate spending by individuals purchasing real estate of DKK 34,600 amounts to around $15 \%$ of the average real estate spending conditional on purchase. To the extent that the reduced credit supply weakened real estate demand and hereby contributed to the considerable drop in Danish real estate prices over the period 2007-2009, this is likely to also have affected consumption through the balance sheet channel (Mian et al., 2013).

\section{Conclusion}

This paper has studied whether the financial crisis spread from distressed banks to households through a contraction of the credit supply. We first argued that banks with a large reliance on non-deposit funding and many assets tied up in illiquid loans were especially exposed to the global credit crunch associated with the financial crisis in 2007-2008 and documented that banks with a high loan-deposit ratio in 2007 reduced their credit supply significantly in the following years relative to banks with a low loans to deposits ratio. We then showed that customers in exposed banks reduced their total borrowing as well as consumption after the financial crisis relative to customers in non-exposed banks. This finding suggests that the tightening of credit by banks exposed to the crisis had significant adverse effects on the households that were their customers.

Besides providing the first compelling evidence that shocks to banks can affect household-level consumption outcomes through the credit supply channel, the paper makes two contributions. First, it shows that switching to a bank with a higher credit supply has a causal positive effect on credit outcomes. This points to measures that facilitate bank switches as potentially powerful tools to mitigate the adverse effects of banking crises in the real economy. Second, it quantifies the contribution of the credit supply channel to the spectacular drop in aggregate private consumption observed in Denmark between 2007 and 2009 and shows that around one third of the consumption loss can plausibly be attributed directly to tightened bank credit. 


\section{References}

Alan, S., Crossley, T., \& Low, H. (2012). Saving on a rainy day, borrowing for a rainy day. Unpublished working paper. (page 6)

Bentolila, S., Jansen, M., Jiménez, G., \& Ruano, S. (2015). When credit dries up: Job losses in the great recession. Unpublished working paper. (page 6)

Browning, M. \& Leth-Petersen, S. (2003). Imputing consumption from income and wealth information*. The Economic Journal, 113(488), 282-301. (page 2, 11)

Brunnermeier, M. (2009). Deciphering the liquidity and credit crunch 2007-2008. The Journal of Economic Perspectives, 23(1), 77-100. (page 2)

Chodorow-Reich, G. (2014). The employment effects of credit market disruptions: Firm-level evidence from the 2008-9 financial crisis. The Quarterly Journal of Economics, 129(1), 1-59. (page 6)

Cornett, M., McNutt, J., Strahan, P., \& Tehranian, H. (2011). Liquidity risk management and credit supply in the financial crisis. Journal of Financial Economics, 101(2), 297-312. (page 3, 9)

Damar, H., Gropp, R., \& Mordel, A. (2014). Banks' financial distress, lending supply and consumption expenditure. Unpublished working paper. (page 6, 19)

Dwenger, N., Fossen, F., \& Simmler, M. (2015). From financial to real economic crisis: Evidence from individual firm-bank relationships in germany. Unpublished working paper. (page 6)

Dynan, K., Mian, A., \& Pence, K. M. (2012). Is a household debt overhang holding back consumption?[with comments and discussion]. Brookings Papers on Economic Activity, (pp. 299-362). (page 4)

Gorton, G. \& Metrick, A. (2012). Securitized banking and the run on repo. Journal of Financial economics, 104(3), 425-451. (page 2)

IMF (2014). Denmark: Crisis Management, Bank Resolution, and Financial Sector Safety Nets - Technical Note. Technical report, International Monetary Fund. (page 7)

Ivashina, V. \& Scharfstein, D. (2010). Bank lending during the financial crisis of 2008. Journal of Financial economics, 97(3), 319-338. (page 3, 9) 
Jiménez, G., Mian, A., Peydró, J.-L., \& Saurina, J. (2014). The real effects of the bank lending channel. Unpublished working paper. (page 6)

Khwaja, A. I. \& Mian, A. (2008). Tracing the impact of bank liquidity shocks: Evidence from an emerging market. The American Economic Review, (pp. 14131442). (page 4, 6, 15)

Klein, M. W., Peek, J., \& Rosengren, E. S. (2002). Troubled banks, impaired foreign direct investment: The role of relative access to credit. American Economic Review, (pp. 664-682). (page 6)

Klemperer, P. (1987). Markets with consumer switching costs. The quarterly journal of economics, (pp. 375-394). (page 5)

Kreiner, C. T., Lassen, D. D., \& Leth-Petersen, S. (2014). Measuring the accuracy of survey responses using administrative register data: evidence from denmark. In Improving the Measurement of Consumer Expenditures. University of Chicago Press. (page 11)

Mian, A., Rao, K., \& Sufi, A. (2013). Household balance sheets, consumption, and the economic slump. The Quarterly Journal of Economics, 128(4), 1687-1726. (page $6,25)$

Mian, A. \& Sufi, A. (2010). Household leverage and the recession of 2007-09. IMF Economic Review, 58(1), 74-117. (page 6)

Munk-Nielsen, A. (2015). Diesel cars and environmental policy. Unpublished working paper. (page 22)

Puri, M., Rocholl, J., \& Steffen, S. (2011). Global retail lending in the aftermath of the us financial crisis: Distinguishing between supply and demand effects. Journal of Financial Economics, 100(3), 556-578. (page 6)

Ramcharan, R., Verani, S., \& Van den Heuvel, S. J. (2015). From wall street to main street: the impact of the financial crisis on consumer credit supply. The Journal of Finance, forthcoming. (page 6)

Rangvid, J. (2013). Den finansielle krise i Danmark. Danish Minstry for Business and Growth. Goverment Committee Report. (page 2, 7, 8)

Reinhart, C. \& Rogoff, K. (2009). This time is different: eight centuries of financial folly. Princeton University Press. (page 2) 
Sharpe, S. A. (1990). Asymmetric information, bank lending, and implicit contracts: A stylized model of customer relationships. The Journal of Finance, 45(4), 10691087. (page 6)

Shin, H. S. (2009). Reflections on northern rock: the bank run that heralded the global financial crisis. The Journal of Economic Perspectives, (pp. 101-120). (page $2,7)$ 
Table 1: Bank lending growth and exposure to the financial crisis

\begin{tabular}{|c|c|c|c|c|}
\hline & \multicolumn{2}{|c|}{ Unweighted } & \multicolumn{2}{|c|}{ Weighted } \\
\hline & Dummy & Continuous & Dummy & Continuous \\
\hline & $(1)$ & (2) & (3) & $(4)$ \\
\hline$\overline{\text { Exposed }}$ & $\begin{array}{c}-0.1764^{* * *} \\
(0.0559)\end{array}$ & $\begin{array}{c}-0.1907 * * * \\
(0.0684)\end{array}$ & $\begin{array}{c}-0.3484^{* *} \\
(0.1384)\end{array}$ & $\begin{array}{c}-0.5215^{* * *} \\
(0.0771)\end{array}$ \\
\hline Constant & $\begin{array}{c}0.1579 * * * \\
(0.0393)\end{array}$ & $\begin{array}{c}0.2708^{* * *} \\
(0.0771)\end{array}$ & $\begin{array}{c}0.2026 \\
(0.1369)\end{array}$ & $\begin{array}{c}0.5546 * * * \\
(0.1038)\end{array}$ \\
\hline Observations & 89 & 89 & 89 & 89 \\
\hline R-squared & 0.1029 & 0.0821 & 0.0679 & 0.3446 \\
\hline
\end{tabular}

Note: Table 1 reports estimates from bank-level regressions where the dependent variable is lending growth over the period 2007-2011 and the explanatory variable captures exposure to the financial crisis. In columns (1) and (3), the explanatory variable is a dummy indicating that the ratio of loans to deposits was above the median at the end of 2007. In columns (2) and (4), the explanatory variable is the ratio of loans to deposits at the end of 2007. In columns (1)-(2), the regressions are unweighted ordinary least squares whereas in columns (3)-(4), the regressions are weighted by total lending in 2007 . Lending growth is winsorized at the 5 th and 95 th percentile to eliminate the influence of mergers and acquisitions. The sample includes all banks covered by the MFI statistics of the Danish Central Bank (excludes the smallest banks), which had positive lending in all years 2005-2012: a total of 89 banks.

Source: MFI Statistics from Danmarks Nationalbank 


\begin{tabular}{|c|c|c|c|c|c|c|}
\hline & All & Exposed & Non-exposed & $\begin{array}{l}\text { Difference } \\
\text { in means }\end{array}$ & $\begin{array}{l}\text { Ratio of } \\
\text { means }\end{array}$ & P-value \\
\hline Age & $\begin{array}{l}35.56 \\
(8.13)\end{array}$ & $\begin{array}{l}35.37 \\
(8.20)\end{array}$ & $\begin{array}{l}35.75 \\
(8.20)\end{array}$ & -0.38 & 0.99 & 0.11 \\
\hline Education, short & $\begin{array}{c}0.27 \\
(0.45)\end{array}$ & $\begin{array}{c}0.28 \\
(0.45)\end{array}$ & $\begin{array}{c}0.27 \\
(0.45)\end{array}$ & 0.00 & 1.01 & 0.91 \\
\hline Education, medium & $\begin{array}{c}0.36 \\
(0.48)\end{array}$ & $\begin{array}{c}0.37 \\
(0.48)\end{array}$ & $\begin{array}{c}0.35 \\
(0.48)\end{array}$ & 0.01 & 1.03 & 0.62 \\
\hline Education, long & $\begin{array}{c}0.24 \\
(0.42)\end{array}$ & $\begin{array}{c}0.23 \\
(0.42)\end{array}$ & $\begin{array}{c}0.24 \\
(0.42)\end{array}$ & 0.00 & 0.99 & 0.91 \\
\hline Female & $\begin{array}{c}0.50 \\
(0.50)\end{array}$ & $\begin{array}{c}0.50 \\
(0.50)\end{array}$ & $\begin{array}{c}0.50 \\
(0.50)\end{array}$ & 0.00 & 1.01 & 0.17 \\
\hline Partner & $\begin{array}{c}0.64 \\
(0.48)\end{array}$ & $\begin{array}{c}0.64 \\
(0.48)\end{array}$ & $\begin{array}{c}0.64 \\
(0.48)\end{array}$ & 0.00 & 1.00 & 0.97 \\
\hline Student & $\begin{array}{c}0.03 \\
(0.18)\end{array}$ & $\begin{array}{c}0.03 \\
(0.18)\end{array}$ & $\begin{array}{c}0.03 \\
(0.18)\end{array}$ & 0.00 & 1.09 & 0.33 \\
\hline Kids & $\begin{array}{c}0.57 \\
(0.50)\end{array}$ & $\begin{array}{c}0.57 \\
(0.50)\end{array}$ & $\begin{array}{c}0.58 \\
(0.50)\end{array}$ & -0.01 & 0.98 & 0.65 \\
\hline Number of cars & $\begin{array}{c}0.46 \\
(0.50)\end{array}$ & $\begin{array}{c}0.47 \\
(0.50)\end{array}$ & $\begin{array}{c}0.45 \\
(0.50)\end{array}$ & 0.02 & 1.04 & 0.57 \\
\hline Disposable income (DKK) & $\begin{array}{l}191,526 \\
(83,151)\end{array}$ & $\begin{array}{l}190,667 \\
(81,541)\end{array}$ & $\begin{array}{l}192,413 \\
(81,541)\end{array}$ & $-1,746$ & 0.99 & 0.74 \\
\hline Total income (DKK) & $\begin{array}{c}255,637 \\
(167,779)\end{array}$ & $\begin{array}{c}256,002 \\
(163,964)\end{array}$ & $\begin{array}{c}255,260 \\
(163,964)\end{array}$ & 742 & 1.00 & 0.95 \\
\hline Unemployment (Percent) & $\begin{array}{c}3.06 \\
(10.64)\end{array}$ & $\begin{array}{c}2.92 \\
(10.31)\end{array}$ & $\begin{array}{c}3.21 \\
(10.31)\end{array}$ & -0.29 & 0.91 & 0.43 \\
\hline Total debt (DKK) & $\begin{array}{c}508,839 \\
(585,181)\end{array}$ & $\begin{array}{c}505,113 \\
(578,078)\end{array}$ & $\begin{array}{c}512,688 \\
(578,078)\end{array}$ & $-7,575$ & 0.99 & 0.86 \\
\hline Bank debt (DKK) & $\begin{array}{c}140,312 \\
(196,634)\end{array}$ & $\begin{array}{c}140,929 \\
(196,294)\end{array}$ & $\begin{array}{c}139,675 \\
(196,294)\end{array}$ & 1,254 & 1.01 & 0.84 \\
\hline Bank deposits (DKK) & $\begin{array}{c}68,187 \\
(158,580)\end{array}$ & $\begin{array}{c}68,982 \\
(158,198)\end{array}$ & $\begin{array}{c}67,366 \\
(158,198)\end{array}$ & 1,617 & 1.02 & 0.57 \\
\hline Imputed spending (DKK) & $\begin{array}{c}217,640 \\
(267,829) \\
\end{array}$ & $\begin{array}{c}216,385 \\
(269,203) \\
\end{array}$ & $\begin{array}{c}218,936 \\
(269,203) \\
\end{array}$ & $-2,552$ & 0.99 & 0.80 \\
\hline Observations & 434,647 & 220,855 & 213,792 & & & \\
\hline
\end{tabular}

Note: Table 2 reports means and standard deviations of personal characteristics of interest for all individuals (Column 1) and individuals whose primary bank in 2007 had a Loan-to-Deposit ratio above the median (Column 2) and below the median (Column 3) respectively; the difference between the means in the two subsamples (Column 4); the ratio of the two means (Column 5) and the p-value of a test of identical means (Column 6). All variables measured in DKK are winsorized at the 1st and 99th percentiles. 


\begin{tabular}{|c|c|c|c|c|c|c|c|c|c|c|c|c|}
\hline & \multicolumn{3}{|c|}{ Total Debt (DKK) } & \multicolumn{3}{|c|}{ Total Bank Debt (DKK) } & \multicolumn{3}{|c|}{ Debt in 2007 Primary bank (DKK) } & \multicolumn{3}{|c|}{ Debt in other banks (DKK) } \\
\hline & $(1)$ & $(2)$ & (3) & $(4)$ & (5) & $(6)$ & (7) & $(8)$ & (9) & $(10)$ & $(11)$ & $(12)$ \\
\hline \multirow[t]{2}{*}{ Exposed } & 7,611 & $-2,009$ & & -891.7 & -923.7 & & $-2,709$ & $-2,406$ & & 1,548 & 1,261 & \\
\hline & $(38,324)$ & $(6,512)$ & & $(5,127)$ & $(1,255)$ & & $(4,558)$ & $(3,565)$ & & $(2,288)$ & $(2,955)$ & \\
\hline \multirow[t]{2}{*}{ Post $\times$ Exposed } & $-16,309 *$ & $-14,114^{* * *}$ & $-14,230^{* * *}$ & $-6,985$ & $-7,401^{* * *}$ & $-7,372^{* * *}$ & $-13,735^{* *}$ & $-14,194 * *$ & $-14,088^{* *}$ & $6,501 * *$ & $6,639 *$ & $6,590 *$ \\
\hline & & $(5,174)$ & $(4,742)$ & $(4,463)$ & $(2,589)$ & $(2,578)$ & $(6,610)$ & $(5,717)$ & $(5,694)$ & $(3,208)$ & $(3,363)$ & $(3,355)$ \\
\hline Covariates-year FE & No & Yes & Yes & No & Yes & Yes & No & Yes & Yes & No & Yes & Yes \\
\hline Municipality-year FE & No & Yes & Yes & No & Yes & Yes & No & Yes & Yes & No & Yes & Yes \\
\hline Industry-year FE & No & Yes & Yes & No & Yes & Yes & No & Yes & Yes & No & Yes & Yes \\
\hline Individual FE & No & No & Yes & No & No & Yes & No & No & Yes & No & No & Yes \\
\hline Observations & 864,047 & 864,047 & 864,047 & 872,228 & 872,097 & 872,097 & 871,541 & 871,410 & 871,410 & 872,228 & 872,097 & 872,097 \\
\hline R-squared & 0.017 & 0.524 & 0.185 & 0.010 & 0.539 & 0.067 & 0.002 & 0.445 & 0.016 & 0.021 & 0.177 & 0.092 \\
\hline
\end{tabular}

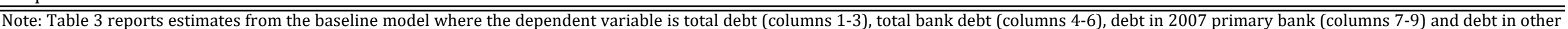

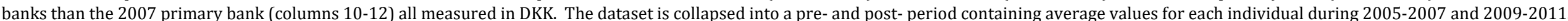

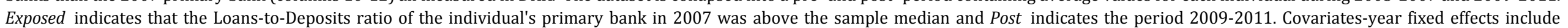

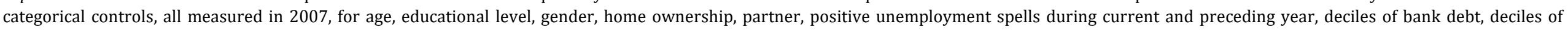

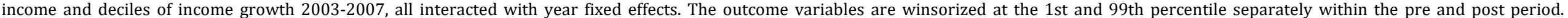

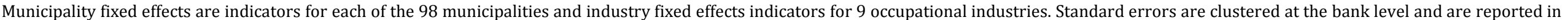
parentheses. ${ }^{*}, * *, * * *$ indicate statistically different from zero at $10 \%, 5 \%$ and $1 \%$ level. 
Pension

Value of stocks Withdrawings Disposable income Unemployment

Deposits (DKK) $\quad(\mathrm{DKK})$
(DKK) (DKK) (Percent)

Exposed

(2)

(3)

\begin{tabular}{lccccc} 
Post × Exposed & $-1,055$ & -56.06 & $36.12 * *$ & -352.1 & -0.083 \\
& $(1,937)$ & $(895.8)$ & $(16.56)$ & $(681.3)$ & $(0.058)$ \\
\hline Covariates-year FE & Yes & Yes & Yes & Yes & Yes \\
Municipality-year FE & Yes & Yes & Yes & Yes & Yes \\
Industry-year FE & Yes & Yes & Yes & Yes & Yes \\
Individual FE & Yes & Yes & Yes & Yes & 855,650 \\
\hline Observations & 872,097 & 872,097 & 872,097 & 864,047 & 0.190 \\
R-squared & 0.047 & 0.008 & 0.027 & 0.443 & 0 \\
\hline \hline
\end{tabular}

Note: Table 4 reports estimates from the baseline model where the dependent variable is total deposits (Column 1), the value of stocks (Column 2), pension withdrawings (Column 3), disposable income (Column 4) and the fraction of the year spent in unemployment measured in percent (5). The dataset is collapsed into a pre- and post- period containing average values for each individual during 2005-2007 and 2009-2011. Exposed indicates that the Loans-to-Deposits ratio of the individual's primary bank in 2007 was above the sample median and Post indicates the period 2009-2011. Covariates-year fixed effects include categorical controls, all measured in 2007, for age, educational level, gender, home ownership, partner, positive unemployment spells during current and preceding year, deciles of bank debt, deciles of income and deciles of income growth 2003-2007, all interacted with year fixed effects. The outcome variables are winsorized at the 1st and 99th percentile separately within the pre and post period. Municipality fixed effects are indicators for each of the 98 municipalities and industry fixed effects indicators for 9 occupational industries. Standard errors are clustered at the bank level and are reported in parentheses. ${ }^{* * *}$, *** indicate statistically different from zero at $10 \%, 5 \%$ and $1 \%$ level. 


\begin{tabular}{|c|c|c|c|c|c|c|c|c|c|}
\hline & \multicolumn{2}{|c|}{ Spending } & \multicolumn{3}{|c|}{ Cars } & \multicolumn{4}{|c|}{ Houses } \\
\hline & \multirow[b]{2}{*}{$\begin{array}{c}\text { Without } \\
\text { stockowners } \\
\text { (DKK) }\end{array}$} & \multirow[b]{2}{*}{$\begin{array}{c}\text { Including } \\
\text { stockowners } \\
(\mathrm{DKK})\end{array}$} & \multirow[b]{2}{*}{$\begin{array}{l}\text { Number of } \\
\text { Active Cars }\end{array}$} & \multirow[b]{2}{*}{$\begin{array}{l}\text { Indicator for } \\
\text { Two Cars }\end{array}$} & \multirow[b]{2}{*}{$\begin{array}{c}\text { Avg. Weight of } \\
\text { Cars }\end{array}$} & \multirow[b]{2}{*}{$\begin{array}{c}\text { Assessed } \\
\text { Property } \\
\text { Value (DKK) }\end{array}$} & \multicolumn{3}{|c|}{ Conditional on House Purchase in the Year } \\
\hline & & & & & & & $\begin{array}{c}\Delta \text { Assessed } \\
\text { Property } \\
\text { Value (DKK) }\end{array}$ & $\begin{array}{c}\Delta \text { Total Debt } \\
(\mathrm{DKK})\end{array}$ & $\begin{array}{l}\Delta \text { House Size } \\
\text { (Sq. meters) }\end{array}$ \\
\hline & (1) & $(2)$ & (3) & (4) & (5) & (6) & (7) & $(8)$ & (9) \\
\hline Exposed & & & & & & & $\begin{array}{c}11,542 * * * \\
(2,655)\end{array}$ & $\begin{array}{l}-3,585 \\
(7,320)\end{array}$ & $\begin{array}{l}0.259 * * \\
(0.127)\end{array}$ \\
\hline Post $\times$ Exposed & $\begin{array}{c}-3,811 * * * \\
(1,365) \\
\end{array}$ & $\begin{array}{c}-4,191 * * * \\
(1,247) \\
\end{array}$ & $\begin{array}{c}-0.00276 * * * \\
(0.000810) \\
\end{array}$ & $\begin{array}{l}-0.00153 * * \\
(0.000629) \\
\end{array}$ & $\begin{array}{l}-2.672 \\
(1.776) \\
\end{array}$ & $\begin{array}{c}-10,240 * * \\
(5,148) \\
\end{array}$ & $\begin{array}{c}-34,644 * * * \\
(6,837) \\
\end{array}$ & $\begin{array}{c}-27,038 * * * \\
(6,881) \\
\end{array}$ & $\begin{array}{c}-0.489 * * \\
(0.191) \\
\end{array}$ \\
\hline Covariates-year FE & Yes & Yes & Yes & Yes & Yes & Yes & Yes & Yes & Yes \\
\hline Municipality-year FE & Yes & Yes & Yes & Yes & Yes & Yes & Yes & Yes & Yes \\
\hline Industry-year FE & Yes & Yes & Yes & Yes & Yes & Yes & Yes & Yes & Yes \\
\hline Individual FE & Yes & Yes & Yes & Yes & Yes & Yes & No & No & No \\
\hline Observations & 669,952 & 864,047 & 872,097 & 872,097 & 397,216 & 864,047 & 239,763 & 239,763 & 235,275 \\
\hline R-squared & 0.163 & 0.149 & 0.022 & 0.014 & 0.016 & 0.093 & 0.250 & 0.203 & 0.017 \\
\hline
\end{tabular}

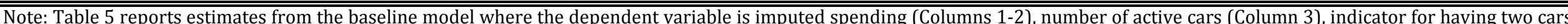

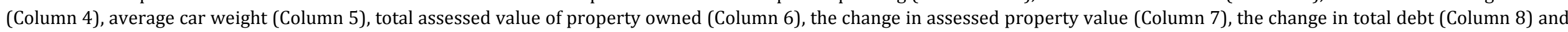

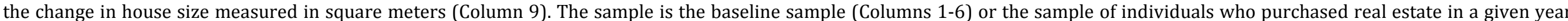

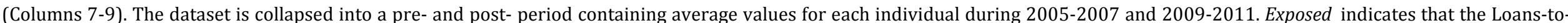

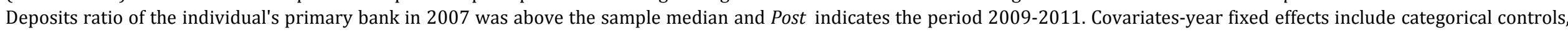

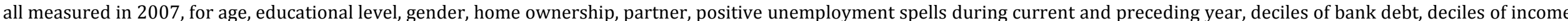

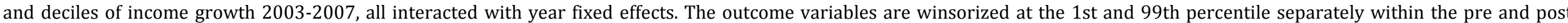

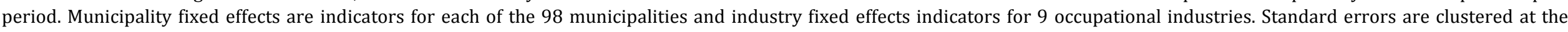
bank level and are reported in parentheses. ${ }^{*}, * * * *$ indicate statistically different from zero at $10 \%, 5 \%$ and $1 \%$ level. 
Table 6: Bank switches

\begin{tabular}{lccc}
\hline \hline & $\begin{array}{c}\text { Total debt } \\
\text { Only non-switchers } \\
\text { (DKK) }\end{array}$ & $\begin{array}{c}\text { Total debt } \\
\text { Only switchers } \\
\text { (DKK) }\end{array}$ & $\begin{array}{c}\text { Total debt } \\
\text { Full sample } \\
\text { (DKK) }\end{array}$ \\
\cline { 2 - 4 } & $(1)$ & $(2)$ & $(3)$ \\
\hline Post $\times$ Exposed & $-21,569^{* * *}$ & $-1,258$ & $-14,300^{* * *}$ \\
Post $\times$ Failed & $(5,092)$ & $(5,956)$ & $(4,881)$ \\
& & & 1,272 \\
Covariates-year FE & & & $(7,048)$ \\
Municipality-year FE & Yes & Yes & Yes \\
Industry-year FE & Yes & Yes & Yes \\
Individual FE & Yes & Yes & Yes \\
\hline Observations & Yes & Yes & Yes \\
R-squared & 632,052 & 231,995 & 933,927 \\
\hline \hline Note Table 6 reports estimates from the baline model where the dependent variable is totaldebt The
\end{tabular}

Note: Table 6 reports estimates from the baseline model where the dependent variable is total debt. The estimating sample includes: individuals in the baseline sample who did not switch banks during the period 2008-2011 (Column 1), individuals in the baseline sample who switched banks during the period 2008-2011 (Column 2) and all individuals in the baseline sample augmented with individuals whose primary bank in 2007 failed during the period 2008-2011 (Column 3). The dataset is collapsed into a pre- and post- period containing average values for each individual during 2005-2007 and 2009-2011.

Exposed indicates that the Loans-to-Deposits ratio of the individual's primary bank in 2007 was above the sample median; Failed indicated that the individual's primary bank in 2007 failed during the period 2008-2011 and Post indicates the period 2009-2011. Covariates-year fixed effects include categorical controls, all measured in 2007, for age, educational level, gender, home ownership, partner, positive unemployment spells during current and preceding year, deciles of bank debt, deciles of income and deciles of income growth 2003-2007, all interacted with year fixed effects. The outcome variables are winsorized at the 1st and 99th percentile separately within the pre and post period. Municipality fixed effects are indicators for each of the 98 municipalities and industry fixed effects indicators for 9 occupational industries. Standard errors are clustered at the bank level and are reported in parentheses. $*, * *, * * *$ indicate statistically different from zero at $10 \%, 5 \%$ and $1 \%$ level. 
Figure 1: Aggregate consumption and bank credit

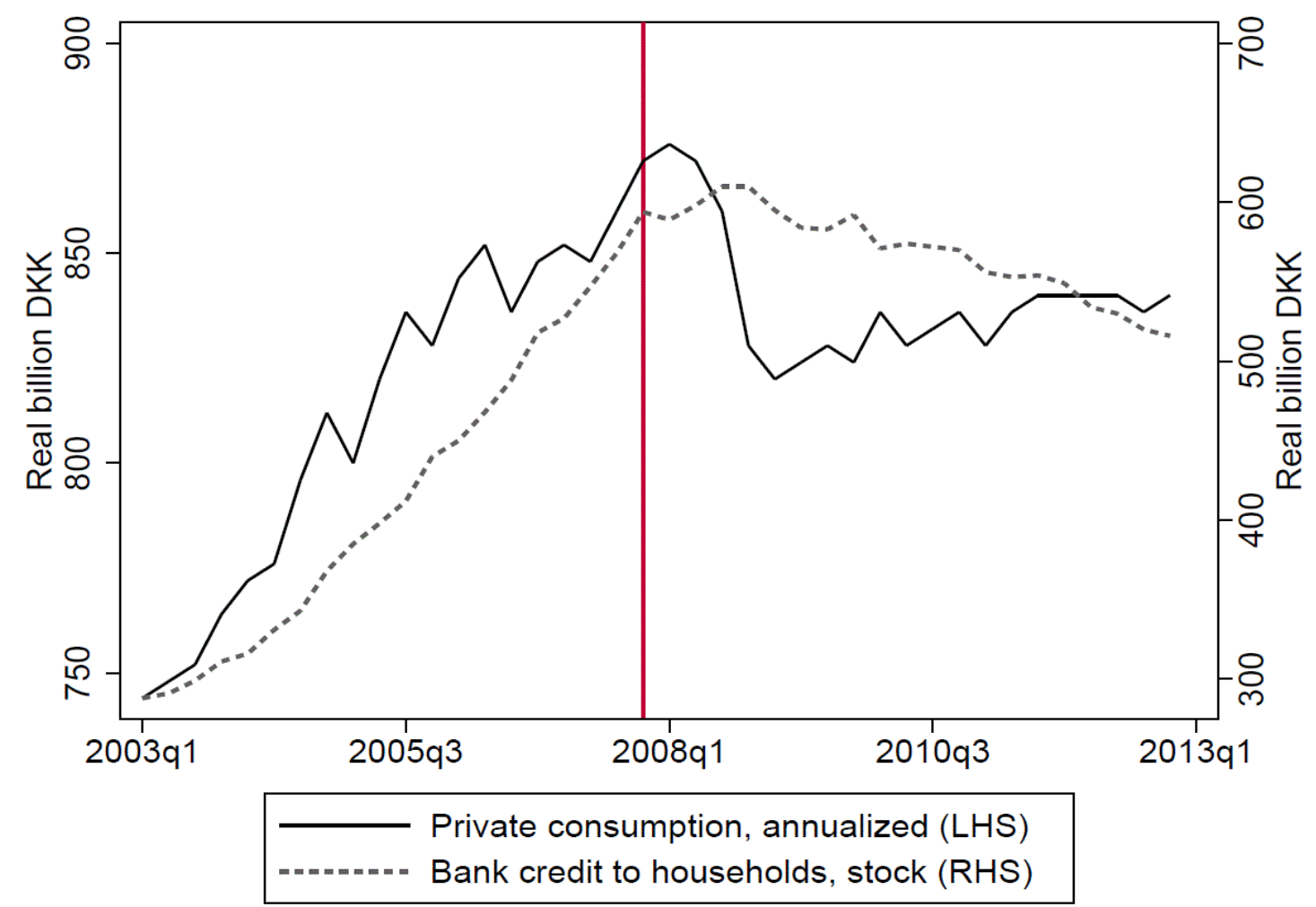

Note: The figure shows the evolution of aggregate private consumption (annualized flow) and bank credit to households (stock) in Denmark over the period 2003Q1-2012Q4 in real 2010-DKK billion.

Source: MFI Statistics from Danmarks Nationalbank and National Accounts from Statistics Denmark

Figure 2: Bank lending and exposure to the financial crisis

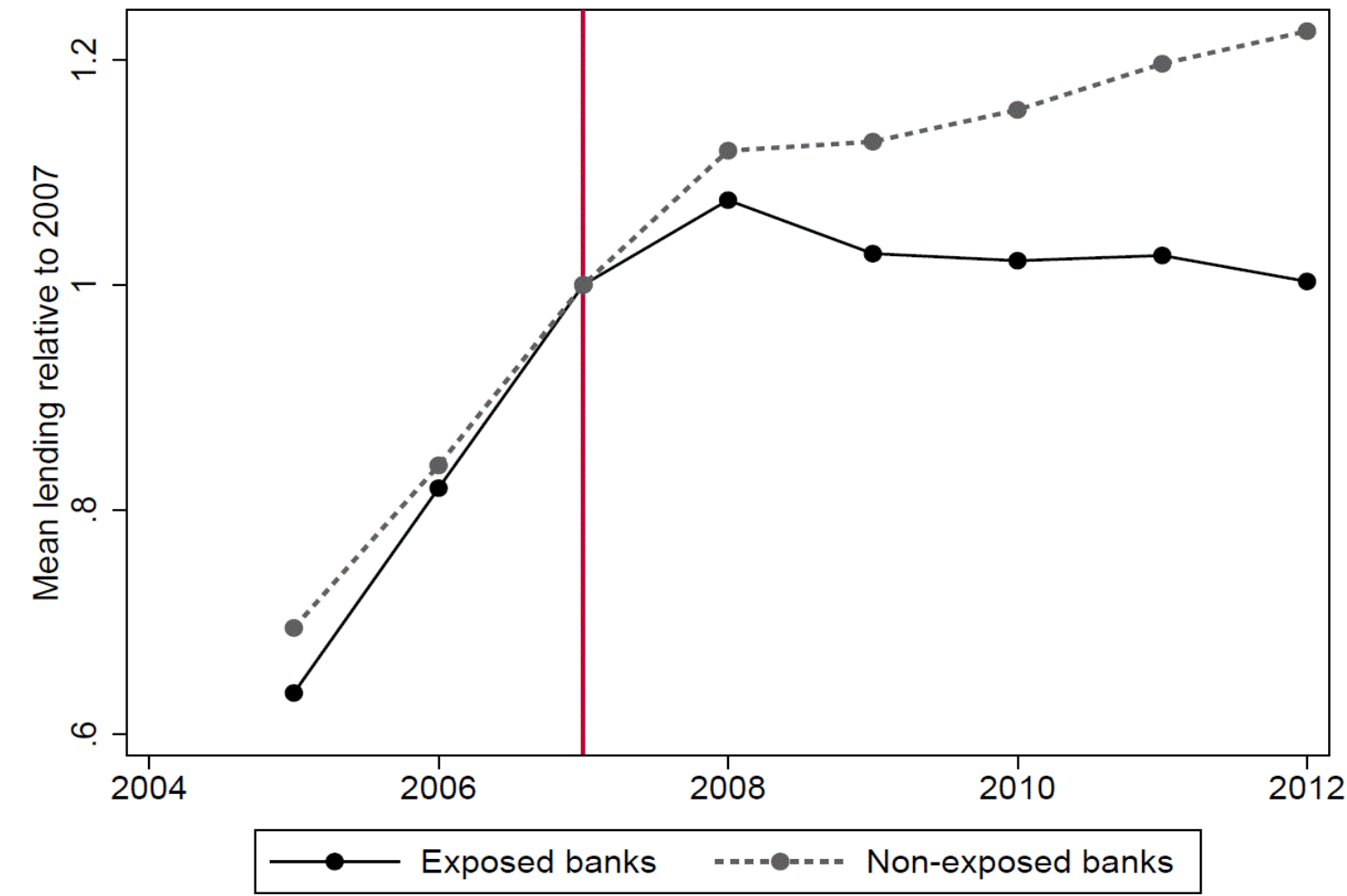

Note: The figure shows lending relative to 2007 by banks with a ratio of loans to deposits ratio in 2007 above the Source: MFI Statistics from Danmarks Nationalbank 


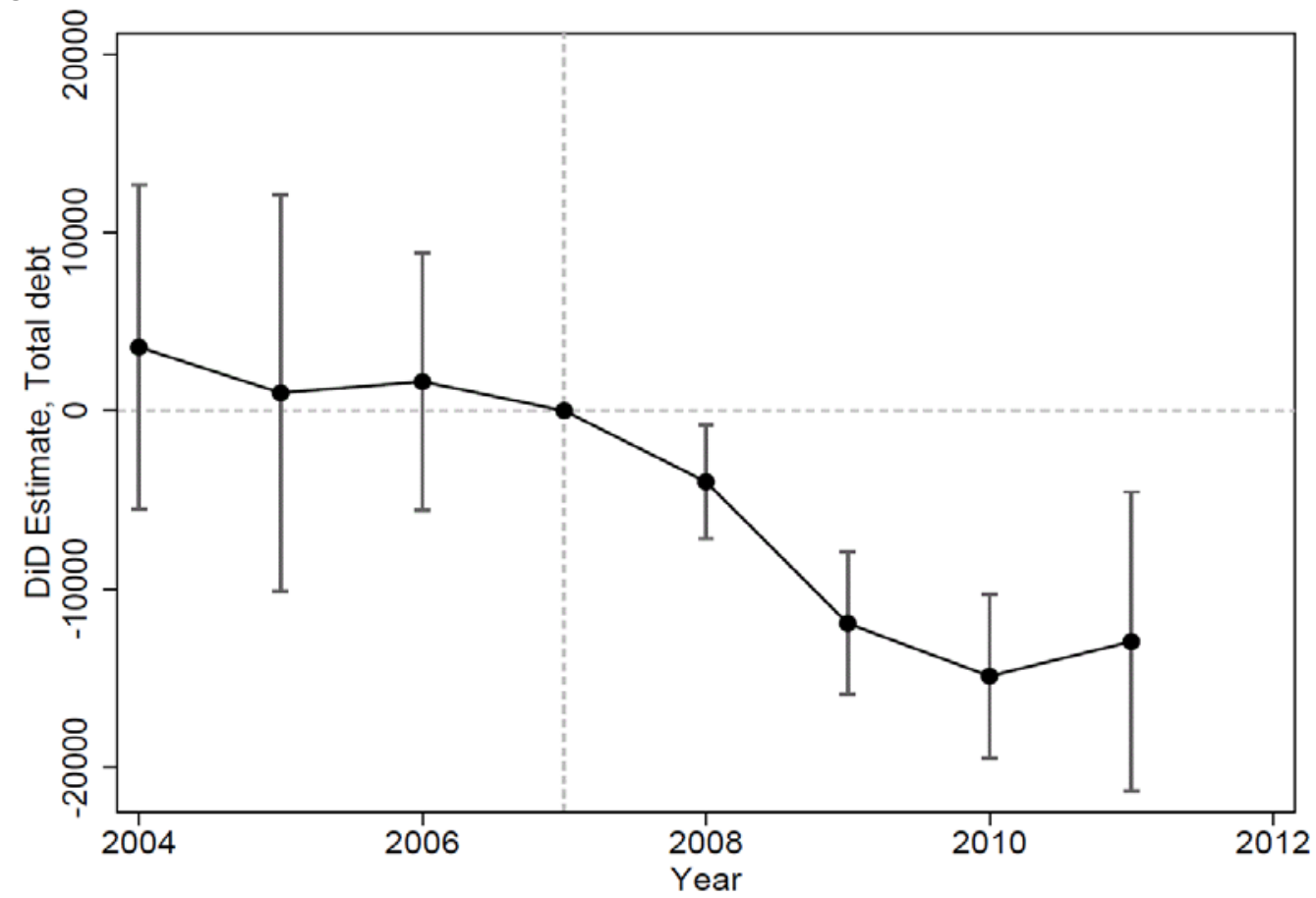

Note: The figure illustrates the results from the baseline model where the dependent variable is total debt. The black dots represent the estimated coefficients on the interaction terms between time dummies and a dummy for individuals whose primary bank in 2007 was exposed to the financial crisis. The gray bars represent $95 \%$ confidence intervals of the point estimates. The model includes individual characteristics, industry dummies and municipality dummies, all measured in 2007 and interacted with a full set of time dummies, as well as individual fixed effects. Precise point estimates and standard errors are reported in Table A1 in the Appendix.

Figure 4: Bank debt, difference-in-difference estimate (in DKK)

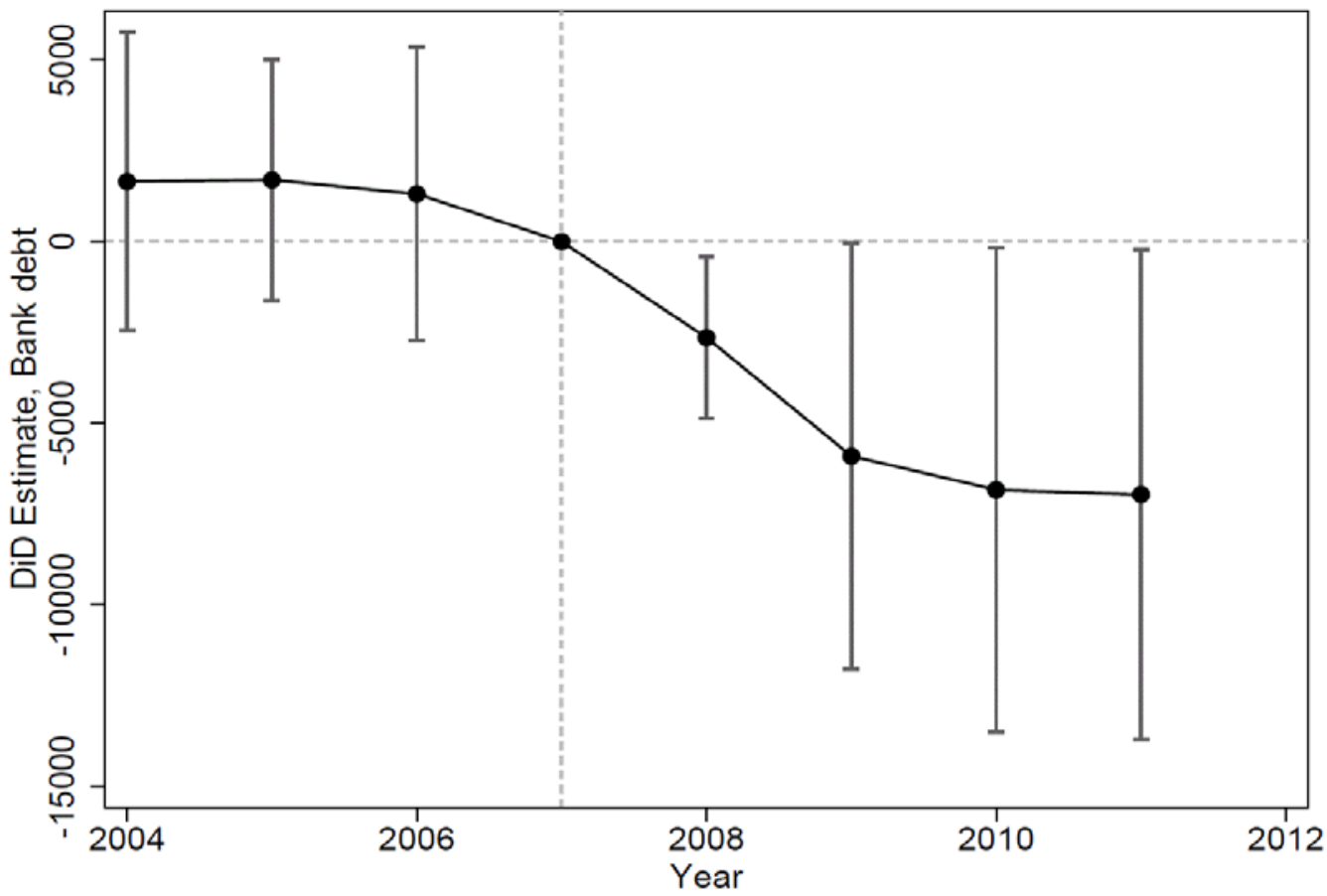

Note: The figure illustrates the results from the baseline model where the dependent variable is bank debt. The black dots represent the estimated coefficients on the interaction terms between time dummies and a dummy for individuals whose primary bank in 2007 was exposed to the financial crisis. The gray bars represent 95\% confidence intervals of the point estimates. The model includes individual characteristics, industry dummies and municipality dummies, all measured in 2007 and interacted with a full set of time dummies, as well as individual fixed effects. Precise point estimates and standard errors are reported in Table A1 in the Appendix. 
Figure 5: Bank debt, within estimate

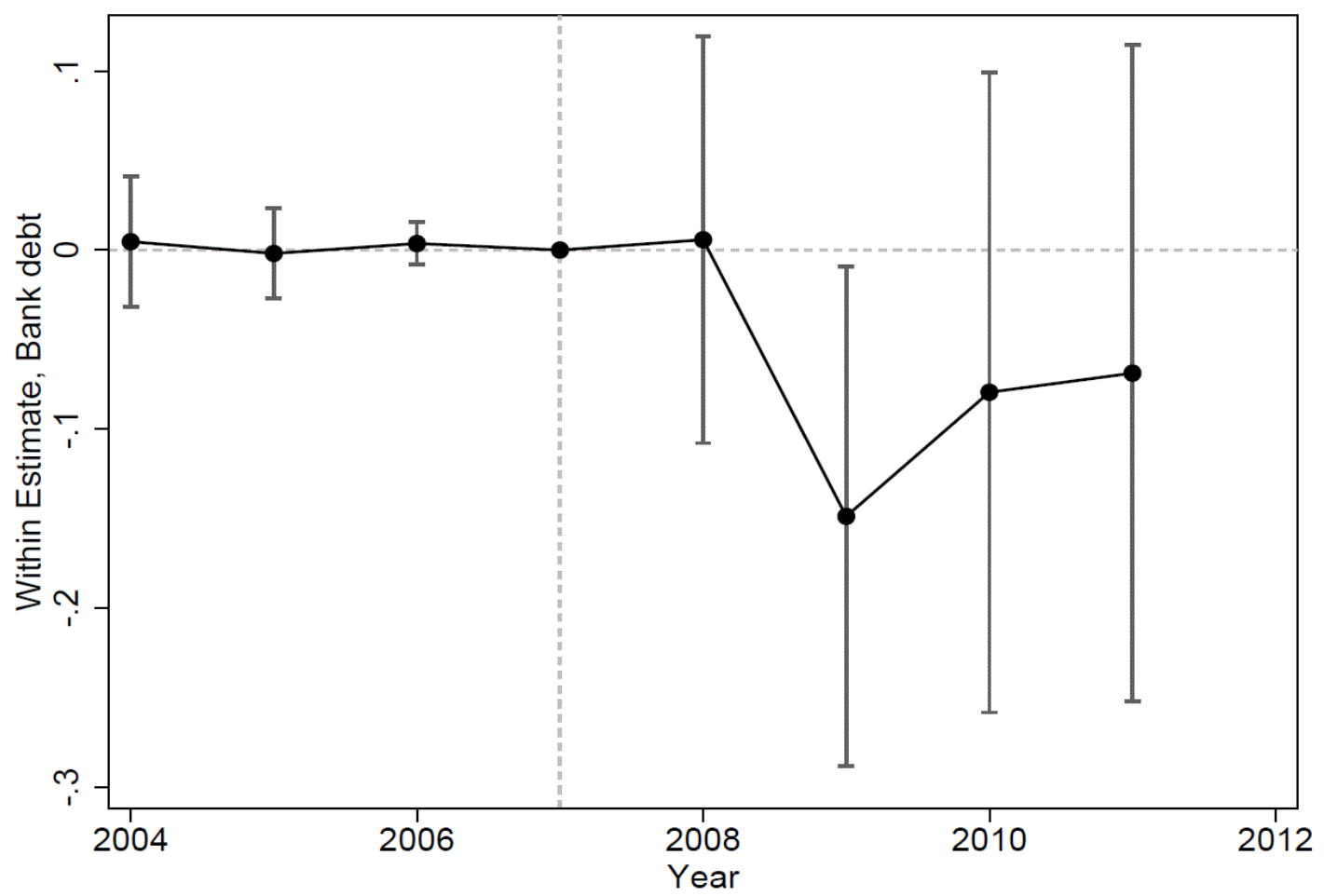

Note: The figure illustrates the results from the account-level model with individual-time fixed effects where the dependent variable is a dummy indicating an increase in the loan balance relative to the previous year. The black dots represent the estimated coefficients on the interaction terms between time dummies and a dummy for banks that were exposed to the financial crisis. The gray bars represent $95 \%$ confidence intervals of the point estimates. Precise point estimates and standard errors are reported in Table A1 in the Appendix.

\section{Figure 6: Liquid assets and withdrawals from pension accounts}

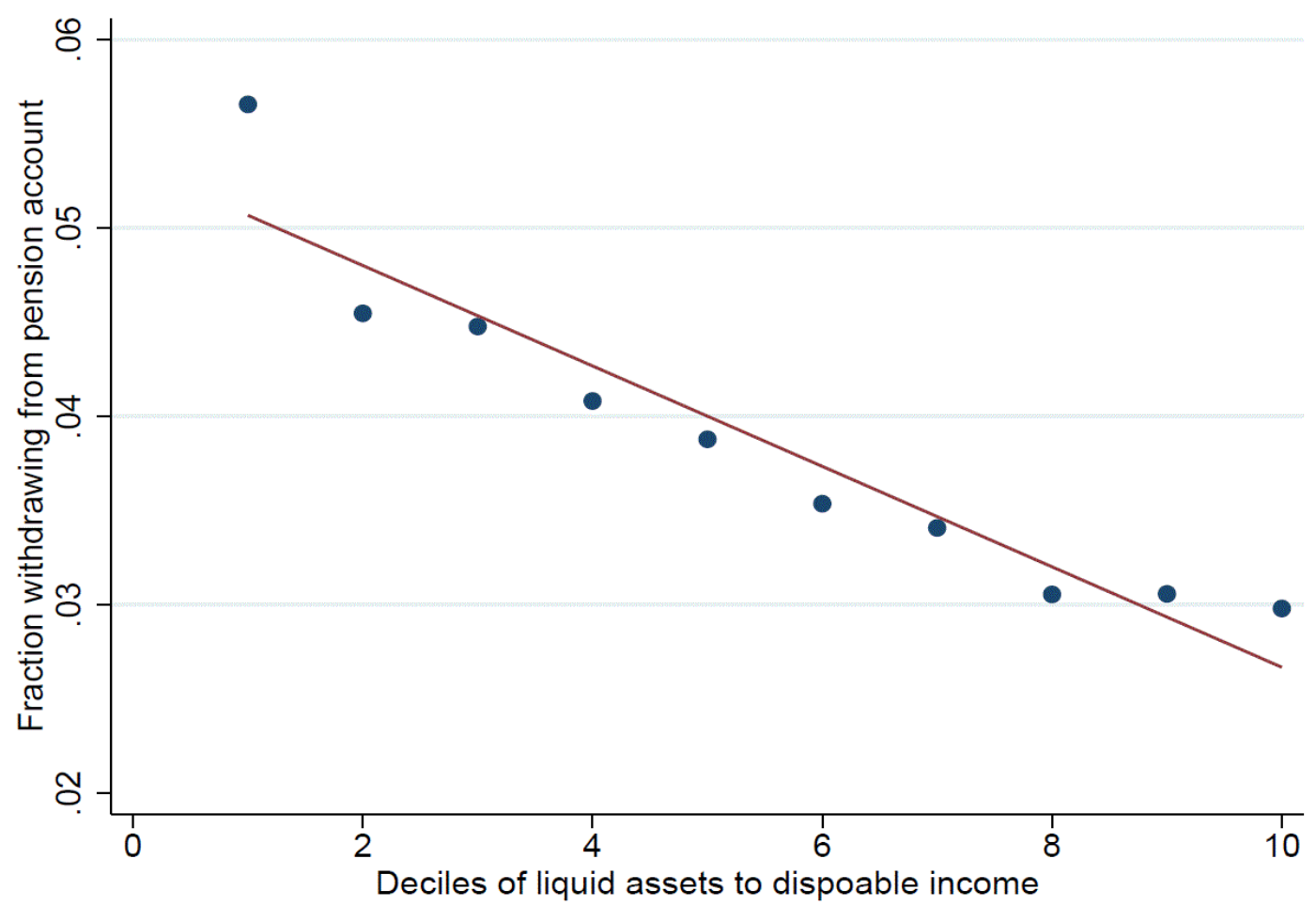

Note: The figure illustrates the correlation between stocks of liquid assets and the propensity to withdraw funds from tax favored pension accounts. The dots indicate the share of individuals withdrawing funds from such accounts in 2009 for each decile of the distribution of the ratio of liquid assets to disposable income. 


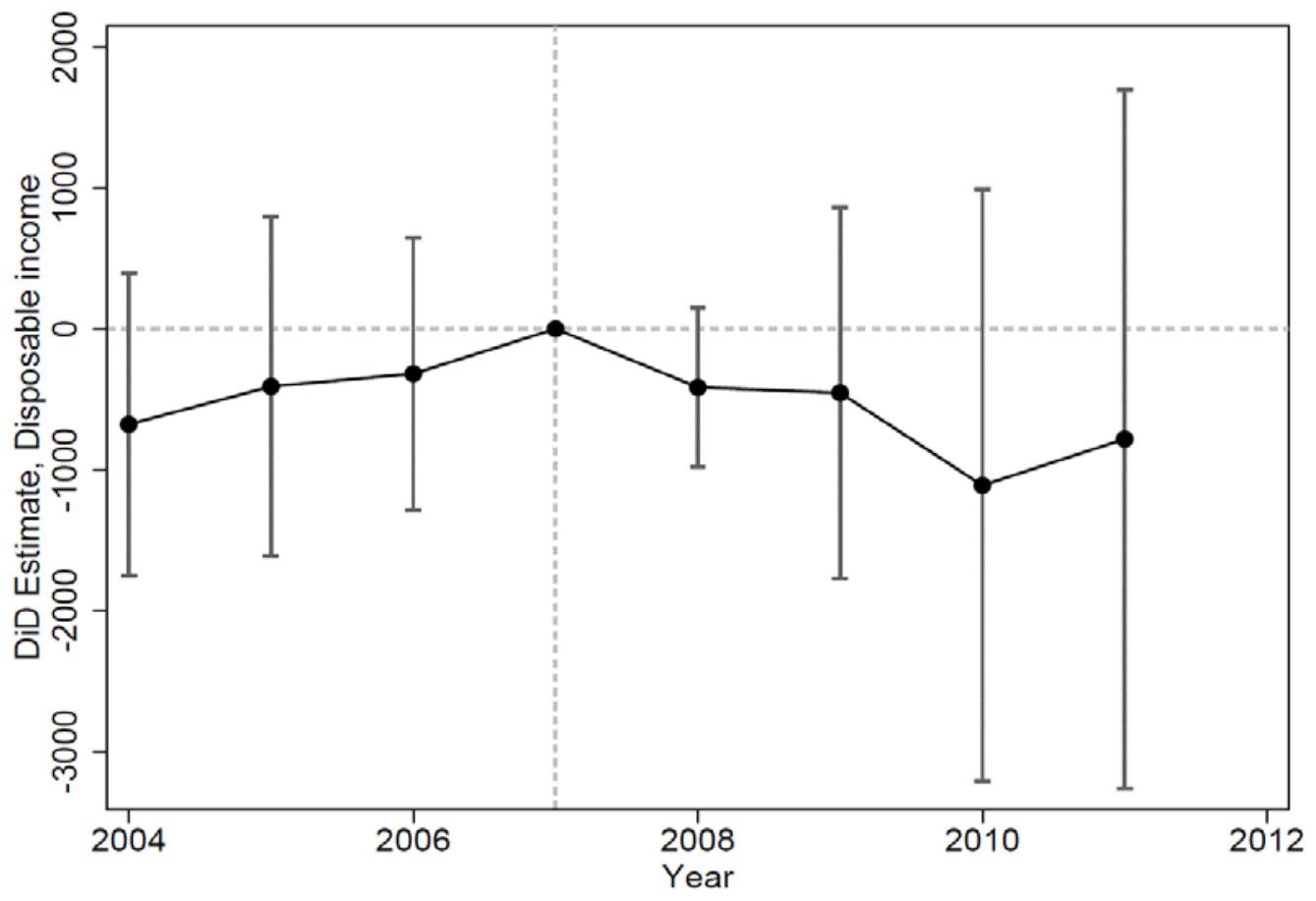

Note: The figure illustrates the results from the baseline model where the dependent variable is disposable income. The black dots represent the estimated coefficients on the interaction terms between time dummies and a dummy for individuals whose primary bank in 2007 was exposed to the financial crisis. The gray bars represent $95 \%$ confidence intervals of the point estimates. The model includes individual characteristics, industry dummies and municipality dummies, all measured in 2007 and interacted with a full set of time dummies, as well as individual fixed effects. Precise point estimates and standard errors are reported in Table A1 in the Appendix.

Figure 8: Imputed spending, difference-in-difference estimate (in DKK)

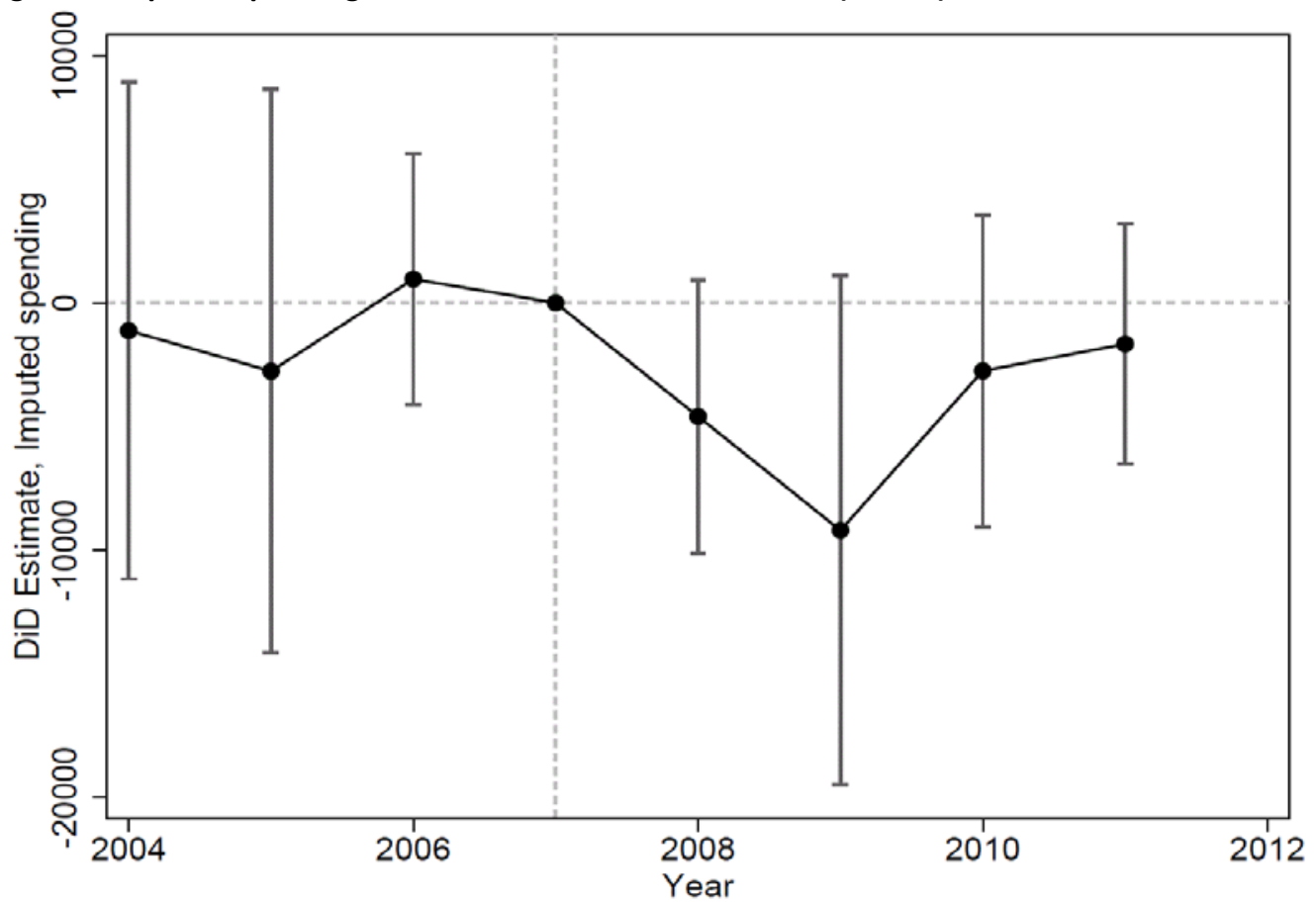

Note: The figure illustrates the results from the baseline model where the dependent variable is imputed spending. The black dots represent the estimated coefficients on the interaction terms between time dummies and a dummy for individuals whose primary bank in 2007 was exposed to the financial crisis. The gray bars represent $95 \%$ confidence intervals of the point estimates. The model includes individual characteristics, industry dummies and municipality dummies, all measured in 2007 and interacted with a full set of time dummies, as well as individual fixed effects. Precise point estimates and standard errors are reported in Table A1 in the Appendix. 
FOR ONLINE PUBLICATION ONLY 
Appendix Table A1: Coefficients and standard errors from figures

\begin{tabular}{|c|c|c|c|c|c|c|}
\hline & $\begin{array}{l}\text { Total debt } \\
\text { (Figure 3) }\end{array}$ & $\begin{array}{l}\text { Bank debt } \\
\text { (Figure 4) }\end{array}$ & $\begin{array}{c}\text { Within } \\
\text { (Figure 5) }\end{array}$ & $\begin{array}{c}\text { Disposable income } \\
\text { (Figure 7) }\end{array}$ & $\begin{array}{l}\text { Spending } \\
\text { (Figure 8) }\end{array}$ & $\begin{array}{c}\text { Spending - no real estate } \\
- \\
\end{array}$ \\
\hline 2004 & $\begin{array}{c}3,572 \\
(4,642)\end{array}$ & $\begin{array}{c}1,656 \\
(2,097)\end{array}$ & $\begin{array}{c}0.0047 \\
(0.0186)\end{array}$ & $\begin{array}{l}-679 \\
(548)\end{array}$ & $\begin{array}{l}-1,117 \\
(5,128)\end{array}$ & $\begin{array}{l}-2,039 \\
(4,168)\end{array}$ \\
\hline 2005 & $\begin{array}{c}999 \\
(5,675)\end{array}$ & $\begin{array}{c}1,699 \\
(1,691)\end{array}$ & $\begin{array}{l}-0.0019 \\
(0.0128)\end{array}$ & $\begin{array}{l}-409 \\
(615)\end{array}$ & $\begin{array}{l}-2,761 \\
(5,814)\end{array}$ & $\begin{array}{l}-4,509 \\
(4,423)\end{array}$ \\
\hline 2006 & $\begin{array}{c}1,631 \\
(3,679)\end{array}$ & $\begin{array}{c}1,315 \\
(2,062)\end{array}$ & $\begin{array}{c}0.0037 \\
(0.0060)\end{array}$ & $\begin{array}{l}-319 \\
(494)\end{array}$ & $\begin{array}{c}965 \\
(2,590)\end{array}$ & $\begin{array}{c}621 \\
(1,621)\end{array}$ \\
\hline 2008 & $\begin{array}{c}-3,984 \\
(1,635)\end{array}$ & $\begin{array}{l}-2,640 \\
(1,135)\end{array}$ & $\begin{array}{c}0.0058 \\
(0.0579)\end{array}$ & $\begin{array}{l}-416 \\
(287)\end{array}$ & $\begin{array}{l}-4,595 \\
(2,823)\end{array}$ & $\begin{array}{l}-3,160 \\
(2,687)\end{array}$ \\
\hline 2009 & $\begin{array}{l}-11,936 \\
(2,041)\end{array}$ & $\begin{array}{l}-5,905 \\
(2,995)\end{array}$ & $\begin{array}{l}-0.1487 \\
(0.0711)\end{array}$ & $\begin{array}{l}-455 \\
(672)\end{array}$ & $\begin{array}{l}-9,201 \\
(5,255)\end{array}$ & $\begin{array}{l}-6,186 \\
(5,146)\end{array}$ \\
\hline 2010 & $\begin{array}{l}-14,902 \\
(2,337)\end{array}$ & $\begin{array}{l}-6,836 \\
(3,400)\end{array}$ & $\begin{array}{l}-0.0794 \\
(0.0912)\end{array}$ & $\begin{array}{l}-1,112 \\
(1,072)\end{array}$ & $\begin{array}{c}-2,750 \\
(3,222)\end{array}$ & $\begin{array}{c}-2,914 \\
(3,473)\end{array}$ \\
\hline 2011 & $\begin{array}{l}-12,948 \\
(4,283)\end{array}$ & $\begin{array}{l}-6,966 \\
(3,441)\end{array}$ & $\begin{array}{l}-0.0688 \\
(0.0935)\end{array}$ & $\begin{array}{c}-783 \\
(1,265)\end{array}$ & $\begin{array}{c}-1,658 \\
(2,477)\end{array}$ & $\begin{array}{c}-425 \\
(2,216)\end{array}$ \\
\hline
\end{tabular}

Note: The table shows the estimated point estimates and standard errors (in parenthesis) used to construct Figures $3,4,5,6,7$ and 8 . The last column shows the estimates from the baseline model where the dependent variable is imputed spending and all individual-years where a real estate transaction takes place are coded as missing. 
Appendix Table A2: Main results with continuous measure of crisis exposure

\begin{tabular}{ccccc}
\hline \hline & Total debt & Bank debt & Disposable income & Spending \\
\hline \multirow{2}{*}{2004} & $-12,126$ & 4,276 & -452 & $-6,016$ \\
& $(16,062)$ & $(4,707)$ & $(1,544)$ & $(12,898)$ \\
2005 & $-13,023$ & 5,391 & 285 & $-10,234$ \\
& $(16,124)$ & $(3,961)$ & $(1,569)$ & $(13,032)$ \\
2006 & $-5,226$ & 2,555 & 200 & -84 \\
& $(10,818)$ & $(4,629)$ & $(1,219)$ & $-13,083$ \\
2008 & $-4,763$ & $-7,320$ & $-1,347$ & $(7,823)$ \\
& $(5,646)$ & $(3,091)$ & $(708)$ & $-26,086$ \\
2009 & $-19,166$ & $-13,055$ & $-1,518$ & $(12,714)$ \\
& $(9,945)$ & $(6,108)$ & $(1,500)$ & $-14,588$ \\
2010 & $-28,022$ & $-13,859$ & $-2,389$ & $(10,978)$ \\
& $(11,488)$ & $(7,024)$ & $(2,487)$ & $-14,976$ \\
& $-28,188$ & $-14,732$ & $-2,180$ & $(9,930)$
\end{tabular}

Note: The table shows the estimated point estimates and standard errors (in parenthesis) from the baseline model when using the ratio of loan to deposits in 2007 as a continuous measure of exposure to the crisis. 
Appendix Figure A1: Mean ratio of loan to deposits for exposed and non-exposed banks

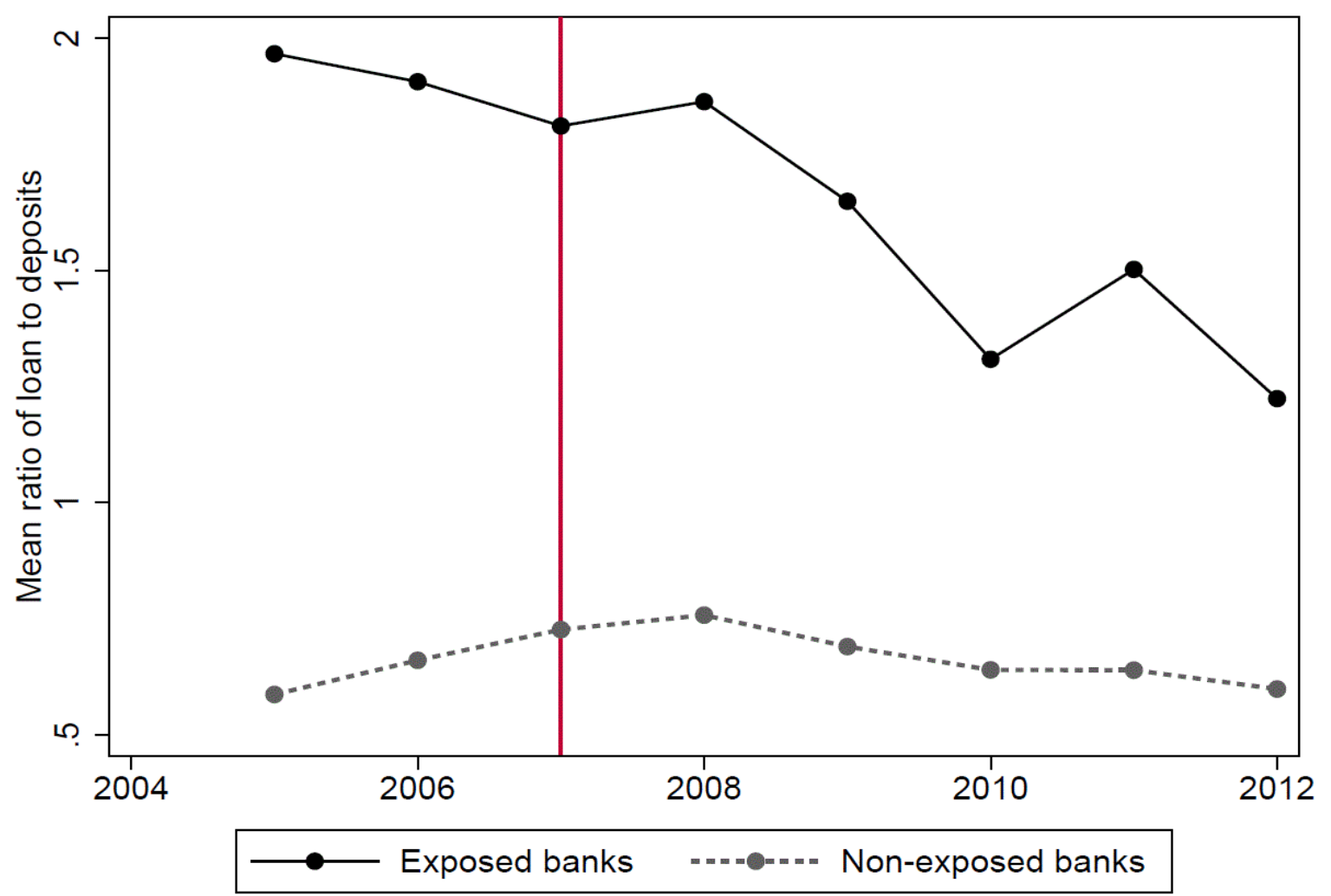

Note: The figure shows the average ratio of loans to deposits over the period 2005-2012 for banks with a ratio of loans to deposits in 2007 above the median (exposed banks) and below (non-exposed banks). The sample consists of 89 banks with positive lending in all years during 2005-2012. 